\title{
Storm-triggered landslides in the Peruvian Andes and implications for topography, carbon cycles, and biodiversity
}

\author{
K. E. Clark ${ }^{1, \mathrm{a}}$, A. J. West ${ }^{2}$, R. G. Hilton ${ }^{3}$, G. P. Asner ${ }^{4}$, C. A. Quesada ${ }^{5}$, M. R. Silman ${ }^{6}$, S. S. Saatchi ${ }^{7}$,

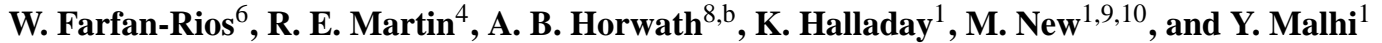 \\ ${ }^{1}$ Environmental Change Institute, School of Geography and the Environment, University of Oxford, \\ Oxford, UK \\ ${ }^{2}$ Department of Earth Sciences, University of Southern California, Los Angeles, CA, USA \\ ${ }^{3}$ Department of Geography, Durham University, Durham, UK \\ ${ }^{4}$ Department of Global Ecology, Carnegie Institution for Science, Stanford, CA, USA \\ ${ }^{5}$ Instituto Nacional de Pesquisas da Amazônia, Manaus, Brazil \\ ${ }^{6}$ Department of Biology and Center for Energy, Environment, and Sustainability, Wake Forest University, \\ Winston-Salem, NC, USA \\ ${ }^{7}$ Jet Propulsion Laboratory, California Institute of Technology, Pasadena, CA, USA \\ ${ }^{8}$ Department of Plant Sciences, University of Cambridge, Cambridge, UK \\ ${ }^{9}$ African Climate and Development Initiative, University of Cape Town, Rondebosch, Cape Town, South Africa \\ ${ }^{10}$ School of International Development, University of East Anglia, Norwich, UK \\ ${ }^{a}$ now at: Department of Earth and Environmental Science, University of Pennsylvania, Philadelphia, PA, USA \\ ${ }^{b}$ now at: Department of Biology, University of Stirling, Stirling, UK \\ Correspondence to: K. E. Clark (kathryn.clark23@gmail.com)
}

Received: 12 July 2015 - Published in Earth Surf. Dynam. Discuss.: 12 August 2015

Revised: 14 December 2015 - Accepted: 22 December 2015 - Published: 20 January 2016

\begin{abstract}
In this study, we assess the geomorphic role of a rare, large-magnitude landslide-triggering event and consider its effect on mountain forest ecosystems and the erosion of organic carbon in an Andean river catchment. Proximal triggers such as large rain storms are known to cause large numbers of landslides, but the relative effects of such low-frequency, high-magnitude events are not well known in the context of more regular, smaller events. We develop a 25 -year duration, annual-resolution landslide inventory by mapping landslide occurrence in the Kosñipata Valley, Peru, from 1988 to 2012 using Landsat, QuickBird, and WorldView satellite images. Catchment-wide landslide rates were high, averaging $0.076 \% \mathrm{yr}^{-1}$ by area. As a result, landslides on average completely turn over hillslopes every $\sim 1320$ years, although our data suggest that landslide occurrence varies spatially and temporally, such that turnover times are likely to be non-uniform. In total, landslides stripped $26 \pm 4 \mathrm{tC} \mathrm{km}^{-2} \mathrm{yr}^{-1}$ of organic carbon from soil (80\%) and vegetation (20\%) during the study period. A single rain storm in March 2010 accounted for $27 \%$ of all landslide area observed during the 25 -year study and accounted for $26 \%$ of the landslide-associated organic carbon flux. An approximately linear magnitude-frequency relationship for annual landslide areas suggests that large storms contribute an equivalent landslide failure area to the sum of lower-frequency landslide events occurring over the same period. However, the spatial distribution of landslides associated with the 2010 storm is distinct. On the basis of precipitation statistics and landscape morphology, we hypothesise that focusing of storm-triggered landslide erosion at lower elevations in the Kosñipata catchment may be characteristic of longer-term patterns. These patterns may have implications for the source and composition of sediments and organic material supplied to river systems of the Amazon Basin, and, through focusing of regular ecological disturbance, for the species composition of forested ecosystems in the region.
\end{abstract}


1

\section{Introduction}

Landslides are major agents of topographic evolution (e.g. Li et al., 2014; Egholm et al., 2013; Ekström and Stark, 2013; Larsen and Montgomery, 2012; Roering et al., 2005; Hovius et al., 1997) and are increasingly recognised for their important biogeochemical and ecological role in mountainous environments because they drive erosion of carbon and nutrients (Pepin et al., 2013; Ramos Scharrón et al., 2012; Hilton et al., 2011; West et al., 2011; Stallard, 1985) and introduce regular cycles of disturbance to ecosystems (Restrepo et al., 2009; Bussmann et al., 2008). Landslides result when slope angles reach a failure threshold (Burbank et al., 1996; Schmidt and Montgomery, 1995; Selby, 1993), which is thought to occur in mountains as rivers incise their channels, leaving steepened hillslopes (Montgomery, 2001; Gilbert, 1877). Landsliding acts to prevent progressive steepening beyond a critical failure angle for bedrock, even as rivers continue to cut downwards (Larsen and Montgomery, 2012; Montgomery and Brandon, 2002; Burbank et al., 1996). However, many slopes prone to landslide failure may remain stable until a proximal triggering event, such as a storm (Lin et al., 2008; Meunier et al., 2008; Restrepo et al., 2003; Densmore and Hovius, 2000) or a large earthquake (Li et al., 2014; Dadson et al., 2004; Keefer, 1994). Intense storms can increase pore pressure from heavy rainfall (Terzaghi, 1951), decreasing soil shear strength and resulting in slope failure (Wang and Sassa, 2003).

By clearing whole sections of forest and transporting materials downslope, landslides can drive fluxes of organic carbon from the biosphere (Hilton et al., 2011; West et al., 2011; Restrepo and Alvarez, 2006), delivering the carbon either into sediments (where recently photosynthesised carbon can be locked away) or into the atmosphere, if ancient organic material in bedrock or soils is exposed and oxidised (Hilton et al., 2014). Links between storm frequency, landslide occurrence, and carbon fluxes could generate erosioncarbon cycle-climate feedbacks (West et al., 2011; Hilton et al., 2008a). Moreover, storm-triggered landslides may link climate to forest disturbance, with implications for ecosystem dynamics (Restrepo et al., 2009). However, for stormtriggered landslides to keep occurring over prolonged periods of time, hillslopes must remain sufficiently steep, which typically occurs in mountains via sustained river incision. Incision is also climatically regulated (Ferrier et al., 2013), providing a mechanism connecting storm activity, erosion, and topographic evolution (e.g. Bilderback et al., 2015), and further linking to organic carbon removal from hillslopes and ecological processes across landscapes.

In this study, we mapped landslides in a mountainous catchment in the Andes of Peru over a 25-year period, including one year (2010) in which a large storm triggered numerous landslides. We quantify landslide rates on an annual basis and use comprehensive data sets on soil and aboveand below-ground biomass to determine the amount of organic carbon stripped from hillslopes. We assess the relative landslide "work", in terms of total landslide area, done in different years to explore the roles of varying magnitudes and frequencies of triggering events, providing a longer-term context for understanding storm-triggered landslides that has not been available in much of the prior research on storm effects. We also evaluate the spatial distribution of landslides with respect to catchment topography and climatic factors that may act as potential longer-term forcing on the location of most active landslide erosion. Finally, we assess the potential role of these spatial patterns in shaping regional topography, determining the composition of sediment delivered to rivers, and influencing forest ecosystems that are repeatedly disturbed by landslide occurrence.

\section{Study area}

The Kosñipata River (Fig. 1) is situated in the eastern Andes of Peru. We focus on the catchment area upstream of a point $\left(13^{\circ} 3^{\prime} 27^{\prime \prime} \mathrm{S}, 71^{\circ} 32^{\prime} 40^{\prime \prime} \mathrm{W}\right)$ just downriver of San Pedro, an area with an eco-lodge and one house and where the San Pedro tributary joins the Kosñipata River. Elevation in the catchment ranges from $1200 \mathrm{~m}$ above sea level $(\mathrm{m})$ to $4000 \mathrm{~m}$, with a mean elevation ( \pm 1 standard deviation) of $2700 \pm 600 \mathrm{~m}$ and a catchment area of $185 \mathrm{~km}^{2}$. The forested area covers $150 \mathrm{~km}^{2}$ and consists of tropical montane cloud forest at high elevations and sub-montane tropical rainforest at lower elevations (Fig. 1a; Horwath, 2011). The area of puna grasslands covers $35 \mathrm{~km}^{2}$ above the timberline at $3300 \pm 250 \mathrm{~m}$ range. The Kosñipata valley is partially contained in Manu National Park, where logging is prohibited. A single unpaved road is located in the valley stretching from high to low elevations. The Kosñipata River flows through the study area and into the Alto Madre de Dios River, which feeds the Madre de Dios River, a tributary of the Amazon River. There are extensive data sets on plants, soils, ecosystem productivity, carbon and nutrient cycling, and climate within the catchment (Malhi et al., 2010). Tree species richness ranges from 40 to 180 species ha $^{-1}$ for trees $\geq 10 \mathrm{~cm}$ diameter at breast height, and total forest $\mathrm{C}$ stocks (Gurdak et al., 2014; Girardin et al., 2013; Horwath, 2011; Gibbon et al., 2010) are representative of the wider Andean region (Saatchi et al., 2011).

The South American low-level jet carries humid winds westward over the Amazon Basin and then south along the flank of the Andes, driving orographic rainfall in the Eastern Cordillera of the central Andes (Espinoza et al., 2015; Lowman and Barros, 2014; Marengo et al., 2004). In the study area, precipitation ranges from 2000 to $5000 \mathrm{~mm} \mathrm{yr}^{-1}$ and is highest at the lowest elevations, decreasing approximately linearly with increase in elevation (Clark et al., 2014; 

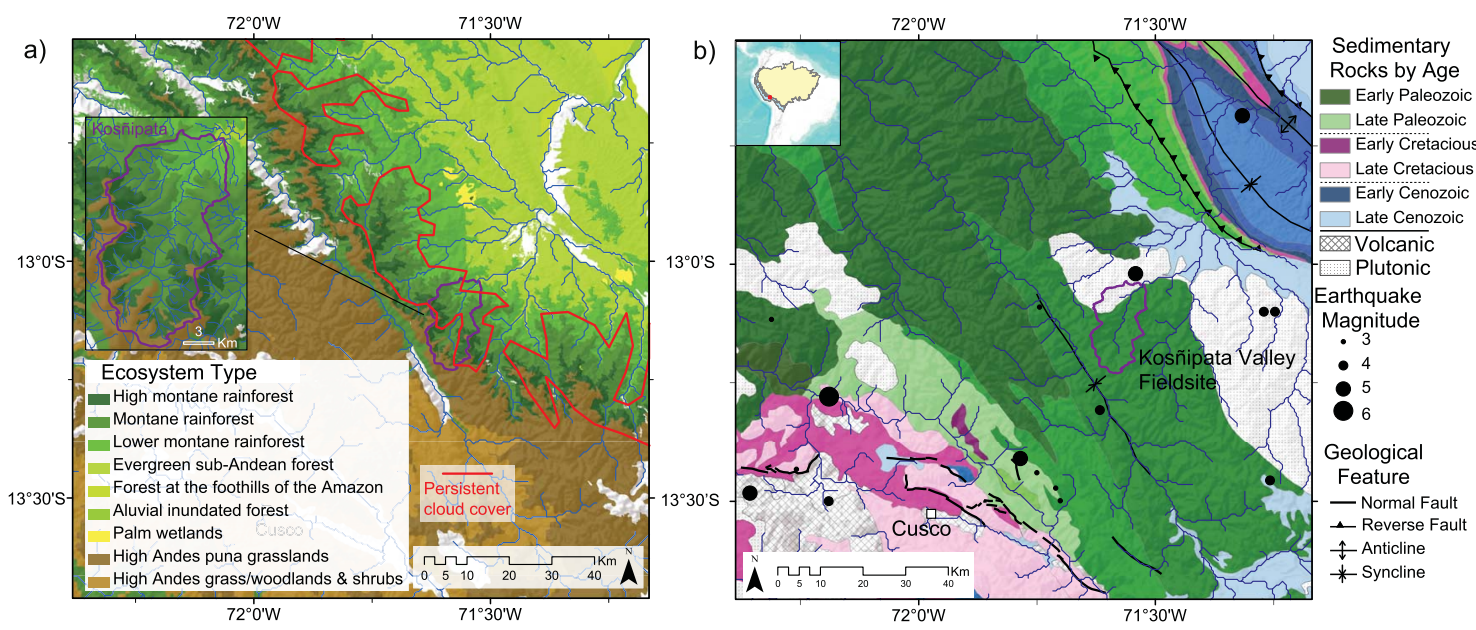

Figure 1. Maps of the study region. (a) Ecosystem types in the eastern Andes of Peru (Consbio, 2011). Bare areas are cities, agriculture, glaciers, and riverbed, with the Kosñipata study catchment magnified in the inset. Areas delimited by red polygons are regions of $>75 \%$ annual cloud cover (Halladay et al., 2012). (b) Georectified geological map (INGEMMET, 2013; Vargas Vilchez and Hipolito Romero, 1998; Carlotto Caillaux et al., 1996; Mendívil Echevarría and Dávila Manrique, 1994); sedimentary rocks are on a scale ranging from dark to light colour within each era. Active faults (Cabrera et al., 1991; Sébrier et al., 1985) and documented earthquakes since 1975 (USGS, $2013 \mathrm{a}$ ) are shown.

Girardin et al., 2014b; Huaraca Huasco et al., 2014). Much of the valley has $>75 \%$ cloud cover throughout the year in a band of persistent cloud that spans much of the eastern Andes, although cloud immersion is restricted to elevations $>\sim 1600 \mathrm{~m}$ (Halladay et al., 2012; Fig. 1a).

The Kosñipata Valley is in the tectonically active setting of the uplifting Eastern Cordillera of the central Andes, associated with subduction of the Nazca Plate under the South American Plate (Gregory-Wodzicki, 2000). Since 1978, there have been $\sim 4$ registered earthquakes larger than magnitude $M=5$ within a distance of $65 \mathrm{~km}$ from the Kosñipata Valley (Fig. 1b; USGS, 2013a; Gregory-Wodzicki, 2000), though significant ground shaking within the Kosñipata Valley has not been reported during the study interval. The Cusco fault zone is $\sim 50 \mathrm{~km}$ southwest of the study site, consisting of normal faults stretching $200 \mathrm{~km}$ long and $15 \mathrm{~km}$ wide parallel to the Andean Plateau (Cabrera et al., 1991) and where deep earthquakes are common (USGS, 2013a; Tavera and Buforn, 2001). In the Andean foothills, $\sim 20 \mathrm{~km}$ northeast of the study site, there is an active fold and thrust belt (Vargas Vilchez and Hipolito Romero, 1998; Sébrier et al., 1985). The bedrock geology in the Kosñipata Valley is representative of the wider eastern Andes (Clark et al., 2013). The catchment is dominated by metamorphosed sedimentary rocks in the high elevations (mostly mudstone protoliths of $\sim 450 \mathrm{Ma}$ ) and a plutonic region in the lower elevations (Carlotto Caillaux et al., 1996; Fig. 1b).

Landslides are a pervasive feature of the landscape in the Kosñipata Valley. In general in the Andes, landslides are a common geomorphic process, with landslide area covering $1-6 \%$ of mountain catchments in parts of Ecuador and Bolivia (Blodgett and Isacks, 2007; Stoyan, 2000), and landslide-associated denudation rates have been estimated in the range of $9 \pm 5 \mathrm{~mm} \mathrm{yr}^{-1}$ (Blodgett and Isacks, 2007). Downstream of the Kosñipata River, detrital cosmogenic nuclide concentrations in river sediments in the Madre de Dios River suggest a denudation rate of $\sim 0.3 \mathrm{~mm} \mathrm{yr}^{-1}$ (Wittmann et al., 2009), although this catchment includes a large lowland floodplain area. Cosmogenic-derived total denudation rates in the high Bolivian Andes range up to $\sim 1.3 \mathrm{~mm} \mathrm{yr}^{-1}$ (Safran et al., 2005) and suspended sediment derived erosion rates up to $1.2 \mathrm{~mm} \mathrm{yr}^{-1}$ (Pepin et al., 2013). The difference between the landslide-associated erosion rates measured in Bolivia (Blodgett and Isacks, 2007) and the catchmentaveraged denudation rates typical of this region has not been widely considered, and a more systematic comparison including data paired from identical catchments could offer fruitful avenues for further investigation. For the purposes of this study, the observation of relatively high landslide rates suggests at the least that landslides are the primary mechanism of hillslope mass removal, as they are in other active mountain belts (Hovius et al., 1997, 2000).

\section{Materials and methods}

\subsection{Landslide mapping}

Landslides within the Kosñipata Valley were manually mapped over a 25-year period from 1988 to 2012 using Landsat 5 (Landsat Thematic Mapper) and Landsat 7 (Landsat Enhanced Thematic Mapper Plus) satellite images (Fig. 2a; USGS, 2013b). There were 38 usable Landsat images for the region over the 25-year period, with 1-3 available for each 
year (see Supplement Table S1). All images were acquired in the dry season (May-October). Landsat images were processed with a standard terrain correction (level 1T) which consists of systematic radiometric and geometric processing using ground control points and a digital elevation model (DEM) for ortho-georectification (USGS, 2013b). The high frequency of the Landsat images made it possible to develop a time series of individual landslides over the entire 25-year duration which has not typically been achieved before in studies at the catchment scale (Hilton et al., 2011; Hovius et al., 1997).

The landslide inventory was produced by manually mapping landslide scars and their deposits in ArcGIS using ArcMap 10.2.1, and by verifying via ground truthing of scars in the field. Mapping involved visually comparing images from one year to the next, specifically evaluating contrasting colour changes that suggest a landslide had occurred. A composite image of Landsat bands 5 (near-infrared, 1.55$1.75 \mu \mathrm{m}$ ), 3 (visible red, $0.63-0.69 \mu \mathrm{m}$ ), and 7 (mid-infrared, $2.08-2.35 \mu \mathrm{m}$ ) was used in order to identify landslide scars with the greatest spectral difference to forest. Bedrock outcrops are minimal in the valley and thus not subject to mislabelling as landslides. Several aerial photographs (from 1963 and 1985) were used to identify and remove pre-1988 landslides from this study.

The landslide areas visible via spectral contrast in the Landsat images include regions of failure, run-out areas, and deposits. In the high-resolution QuickBird and WorldView imagery, we were sometimes able to distinguish scars from deposits, but not systematically enough to separately categorise these for the full landslide catalogue in this study. One 2007 landslide was coupled to a particularly large debris flow and stood out within our inventory, with the $1.7 \mathrm{~km}$ long flow comprising $\sim 5 \%$ of the landslide area in the total inventory from 1988 to 2012. With this one exception, we consider all areas with visible contrast outside of river channels as being "landslide" area (e.g. see Fig. 2a and inset photo). When considering the slope distribution of landslide areas, the deposit areas introduce some bias (see further discussion in Sect. 4.2, below). For the purposes of quantifying biomass disturbance and organic carbon fluxes associated with landslide activity, the convolution of scars and deposits is justified on the basis that all of these areas were covered in forest prior to landslide occurrence and were then displaced during landslide failure. However, the fate of vegetation and soil carbon from scars vs. deposits may differ, as discussed below. Moreover, soil organic carbon (SOC) in low-slope depositional areas buried by landslide deposits may be less likely to erode than SOC not buried underneath landslides. Since this buried material is included in our calculation of the amount of SOC mobilised by landslides, we may to some extent overestimate landslideassociated SOC mobilisation and the resulting amount of carbon accessible for fluvial transport. Future landslide mapping work, taking advantage of even higher resolution imagery than available in this study, would benefit from the effort to explicitly distinguish scars and deposits for full inventories.

The Landsat images had a mean visibility of $67 \%$ that varied year to year (Table S2; Fig. 3a). Non-visible portions were due to topographic shadow, cloud shadow, and no-data strips on Landsat 7 images post-2002 (following failure of the satellite's scan line corrector). Duplicate or triplicate images were used in most years, so landslides obscured by cloud shadow or no-data strips were likely to be spotted within a year of their occurrence. Topographic shadow produced by hillslopes covered a minimum of $21 \%$ of the study area $\left(35 \mathrm{~km}^{2}\right.$ out of $\left.185 \mathrm{~km}^{2}\right)$, predominantly on southwest-facing slopes ( $223 \pm 52^{\circ}$ azimuth), and was consistently present between images. Landslides that fell within these shadow areas were not visible. Using QuickBird imagery from 2005 (which covers $54 \%$ of the study area) we found that the Landsat topographic shadow areas have a similar area covered by landslides as the visible areas; $26 \%$ of the QuickBird-mapped landslide area fell within Landsat topographic shadow areas, and these areas encompass a similar $22 \%$ of the total image area. We thus infer that landslide occurrence under Landsat topographic shadow is approximately equivalent to that in the visible portion of the Landsat images. On this basis, we estimate an error of $\sim 20 \%$ in our landslide inventory due to missed landslides under topographic shadow.

Small-area landslides are not fully accounted for by our mapping approach due to the Landsat grid resolution of $30 \mathrm{~m} \times 30 \mathrm{~m}$ (Stark and Hovius, 2001). In addition, Landsat images may not allow distinguishing of clumped landslides (see Marc and Hovius, 2015; Li et al., 2014). We assessed the potential bias by comparing the Landsat imagery with QuickBird imagery from 2005 (at $2.4 \mathrm{~m} \times 2.4 \mathrm{~m}$ resolution). Specifically, we compared landslides mapped from portions of a 2005 QuickBird image that are visible in the Landsat imagery (i.e. not in topographic shadow, discussed above) with the Landsat-derived landslides mapped from 1988 to 2005 that had not recovered by 2005 . The difference in landslide area is $181760 \mathrm{~m}^{2}$, equivalent to $\sim 25 \%$ of the total landslide area. The area-frequency relationships (Malamud et al., 2004, and references therein) for the two data sets show similar power law relationships for large landslides (Fig. 4) and illustrate that the different total landslide areas can be attributed mainly to missing small landslides $\left(<4000 \mathrm{~m}^{2}\right)$ in the Landsat-derived maps. These small landslides contribute $\sim 80 \%$ of the observed difference, with the remaining difference attributable to three larger landslides (total area $30500 \mathrm{~m}^{2}$ ) missed due to other reasons such as image quality. Based on the difference between total landslide area mapped via QuickBird vs. Landsat imagery, we estimate an error of $\sim 20 \%$ in our landslide inventory from missing small landslides and $<5 \%$ error from missing larger landslides. 


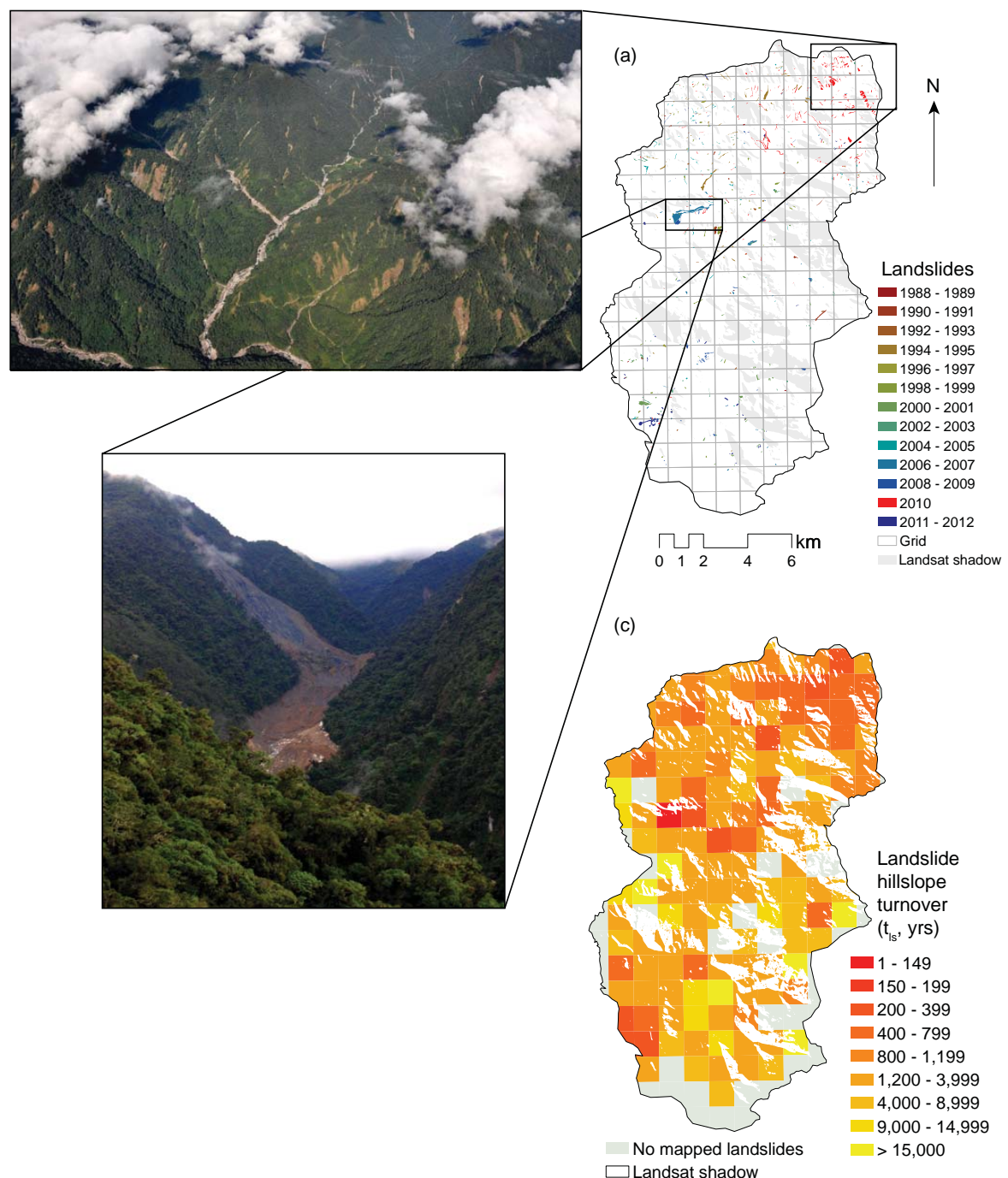

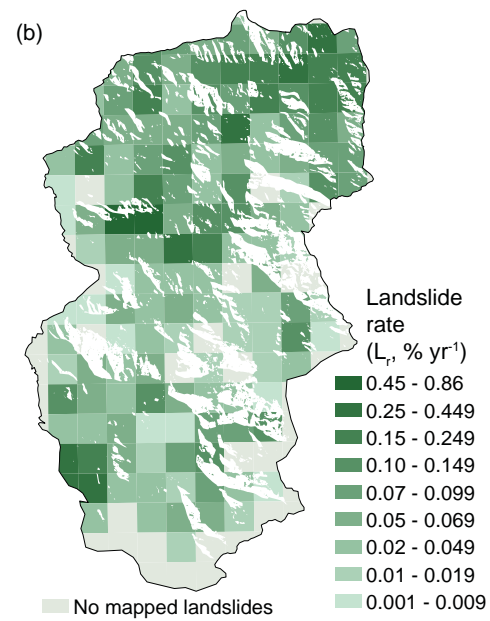

$\square$ Landsat shadow

(d)

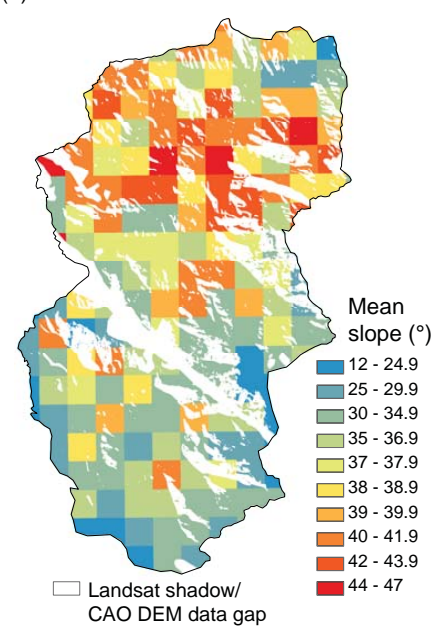

Figure 2. (a) Landslides over the 25-year study period mapped from Landsat satellite images with annual resolution, with Landsat topographic shadow regions in light grey. Photographs of the 2010 landslides (upper) taken by Gregory P. Asner from the Carnagie Airborne Observatory (CAO) in 2013, and of the largest landslide in the study in 2007 (lower) taken by William Farfan-Rios from the ground in 2011. (b) Landslide rates $\left(R_{\mathrm{ls}}, \% \mathrm{yr}^{-1}\right)$ calculated by $1 \mathrm{~km}^{2}$ grid cell. (c) Hillslope turnover $\left(t_{\mathrm{ls}}\right.$, yr) rates calculated as the time for landslides, at the current measured rate $\left(R_{\mathrm{ls}}\right)$, to impact $100 \%$ of each cell area. (d) Catchment slopes calculated over a $1 \mathrm{~km}^{2}$ grid for the visible portion of the study area using the CAO DEM with $3 \mathrm{~m} \times 3 \mathrm{~m}$ resolution.

\subsection{Landslide rates, turnover times, and landslide susceptibility}

We calculated landslide rate $\left(R_{\mathrm{ls}}, \% \mathrm{yr}^{-1}\right)$ as the percentage of landslide area $\left(A_{\mathrm{ls}}\right)$ per unit catchment area $\left(A_{\text {catchment }}\right)$, i.e. $R_{\mathrm{ls}}=100 \times A_{\mathrm{ls}} / A_{\text {catchment }} \times 1 / 25 \mathrm{yr}$ for all landslide area observed during the 25 -year study period. To assess the spatial distribution of landslides throughout the study area, we determined rates by $1 \mathrm{~km}^{2}$ grid cells (Fig. 2b).

The average rate of slope turnover due to landslides $\left(t_{\mathrm{ls}}\right)$ is the inverse of landslide rate. This metric reflects the time required for landslides to impact all of the landscape, solely based on their rate of occurrence (Hilton et al., 2011; Re- strepo et al., 2009). $t_{\mathrm{ls}}$ was quantified over the visible portion of the study area in $1 \mathrm{~km}^{2}$ cells (Fig. 2c).

To assess how landslide rate varies with elevation and hillslope angle, we divided each landslide polygon into $3 \mathrm{~m} \times 3 \mathrm{~m}$ cells consistent with the Carnegie Airborne Observatory (CAO) digital elevation model (DEM; Asner et al., 2012; see Appendix A). We used the resulting $3 \mathrm{~m}$ grid to calculate histograms of landslide areas and total catchment area as a function elevation and slope using $300 \mathrm{~m}$ and $1^{\circ}$ intervals, respectively (Figs. 5, 6). We also defined landslide susceptibility $\left(S_{\mathrm{ls}}\right)$ for a given range of elevation or slope angle values, as the ratio of the number of landslide cells in each elevation (or slope) range, divided by the total number 

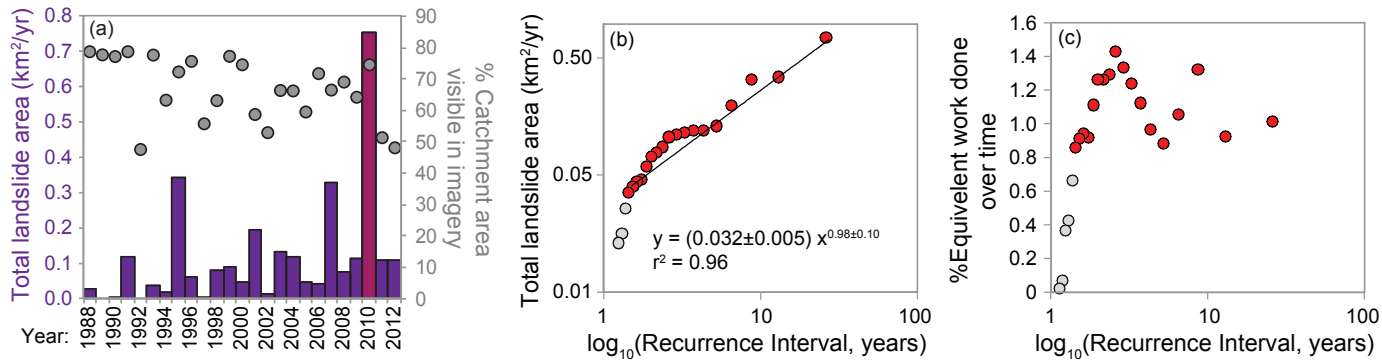

Figure 3. (a) Total area of landslides occurring each year in the data set from this study (coloured bars), along with the percent area visible in the images used for each year (grey points). (b) Magnitude-frequency relationship for landslide areas mapped in each year; red points are included in the regression, while grey points are excluded since these lowest-magnitude years depart from the linear relationship. (c) Estimate of integrated work done by repeated events characteristic of given return times (see Sect. 5.1 in main text). Landslide area mapped in 2010 was significantly higher than any other year because of landslides triggered by the large storm in March 2010, but above a threshold magnitude, the integrated long-term landslide area triggered by repeated events of smaller magnitude is similar to that done by larger, rarer events in this data set, as revealed by the similar percent of equivalent work done for years across a wide range of inferred recurrence interval.

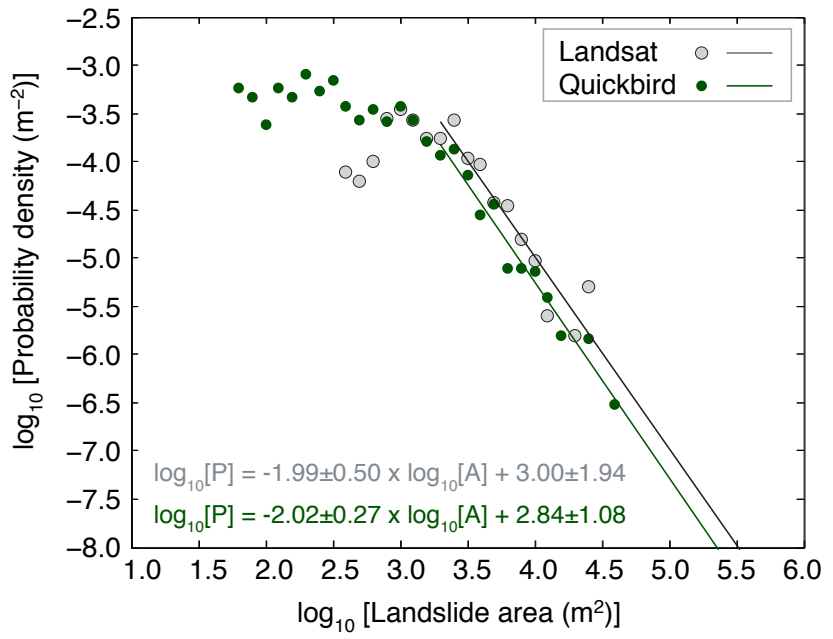

Figure 4. Landslide area-frequency diagram for all landslides mapped from 1988 to 2005 in a region of the Landsat image that overlapped with a QuickBird image from 2005, and for all landslides present in the Landsat visible region of the QuickBird image. The higher frequency of small landslides in the QuickBird inventory can be explained by the higher resolution of this image ( $2.4 \mathrm{~m} \times 2.4 \mathrm{~m}$, compared to $30 \mathrm{~m} \times 30 \mathrm{~m}$ for Landsat). The power law tails of the two inventories are similar.

of catchment cells in the equivalent range. Consistent with the landslide rate analysis, we only used catchment cells in the portion of the study area visible in the Landsat images.

\subsection{Calculation of carbon stripped from hillslopes by landslides}

\subsubsection{General approach to calculating landslide-associated carbon fluxes}

We seek to quantify the amount of organic carbon mobilised by landslides at the catchment scale. This requires knowledge of the spatial distribution of carbon stocks on forested hillslopes at this scale. One approach is to use forest inventory maps derived from field surveys, aerial imagery, or other remote sensing observations (Asner et al., 2010; Saatchi et al., 2007) along with mapped landslides (e.g. Ramos Scharrón et al., 2012; West et al., 2011). However, such forest inventories do not typically capture below-ground or soil carbon stocks, the latter of which can make up the majority of total organic carbon in the landscape (Eswaran et al., 1993). Maps of soil $\mathrm{C}$ can be estimated from soil surveys together with knowledge of the $\mathrm{C}$ content in each soil type (Ramos Scharrón et al., 2012), but sufficiently detailed soil surveys are often unavailable, and it is also difficult to test the key assumption that $\mathrm{C}$ content is constant for a given soil type.

An alternative approach, which we adopt in this study, is to use empirical trends in $\mathrm{C}$ stocks as a function of elevation, and to assign landslide area at a given elevation with a $\mathrm{C}$ stock value representative of that elevation (Hilton et al., 2011). Scatter in the relationship between elevation and C stocks (Fig. 7, Table 1) means these trends do not provide the basis for a robust map of $\mathrm{C}$ stocks, nor a precise value for any single individual landslide. However, landslides in a setting like the Kosñipata Valley occur distributed across the catchment area at a given elevation, and the large number of landslides effectively samples from the observed scatter in $\mathrm{C}$ stocks. This averaging means that, when we sum together estimates of $\mathrm{C}$ stock stripped by all landslides across the catchment, we can estimate a representative mean value for the total flux of landslide-associated carbon. An implicit assumption is that there is not a systematic, coincident spatial bias in both landslide location and $\mathrm{C}$ stock at a given elevation (e.g. see discussion of potential slope biases on $\mathrm{C}$ stock estimates, below). 
Table 1. Regressions for basin-wide carbon stocks $\left(\mathrm{tC} \mathrm{km}^{-2}\right)$ for the Kosñipata Valley.

\begin{tabular}{lrrrl}
\hline Equation & Number of plots & $R^{2}$ & $P$ & Source of data \\
\hline Soil $=4.01 \pm 4.64 \times$ elevation $+16665.22 \pm 11753.06$ & 11 (with 6 to & 0.08 & 0.19 & This study \\
& 51 subplots) & & & \\
AGLB $=-1.16 \pm 0.65 \times$ elevation $+8553.71 \pm 1644.36$ & 13 & 0.22 & 0.10 & This study \\
BGLB $=-0.22 \pm 0.13 \times$ elevation $+2237.09 \pm 280.18$ & 6 & 0.43 & 0.16 & Girardin et al. (2010) \\
\hline
\end{tabular}

AGLB: above-ground living biomass (includes tree stems). BGLB: below-ground living biomass (includes fine and coarse roots).

\subsubsection{Carbon stocks as a function of elevation}

To constrain trends in C stocks with elevation in the Kosñipata catchment, we collated soil and vegetation data sets, taking advantage of the numerous plot studies in this region. The data sets include soil carbon stocks, above-ground living biomass (trees), and root carbon stocks (Girardin et al., 2010). Each data set consisted of data from 6 to 13 plots along the altitudinal gradient (Fig. 7). Linear regressions of $\mathrm{C}$ stock $\left(\mathrm{tC} \mathrm{km}^{-2}\right)$ versus elevation $(\mathrm{m})$ were determined for the soil, above-ground living biomass, and roots separately (Hilton et al., 2011) and are reported in Table 1. For aboveground living biomass, we assumed a wood carbon concentration of $46 \%$ measured in stems and leaves $(n=130)$ throughout the Kosñipata Valley (Rao, 2011). The trend in above-ground biomass versus elevation from this data set fits within the range reported by Asner et al. (2014). Additionally, data on wood debris carbon stocks (Gurdak et al., 2014) and epiphyte carbon stocks (Horwath, 2011) are available but were not used in the carbon stock analysis because (i) these comprise a small proportion of the total biomass (see below) and (ii) do not show systematic change with elevation, precluding the use of our elevation-based approach for these biomass components.

For SOC stocks, we used data from soil pits along the altitudinal gradient. Pits were dug at 11 forest plots, each with 6 to 51 individual soil pits per plot. Soil pits were dug from the surface at 0.05 to $0.5 \mathrm{~m}$ depth intervals until reaching bedrock, which was typically found at $\sim 1 \mathrm{~m}$ depth (see Table S3). Carbon stocks were determined by multiplying interval depth (m) and measured soil organic carbon content (\%OC) by bulk density $\left(\mathrm{g} \mathrm{cm}^{-3}\right)$ for each soil layer. \%OC was measured at each layer for every pit. For each plot one pit was measured for bulk density at the following intervals: $0-5,5-10,10-20,20-30,30-50,50-100$, and $100-150 \mathrm{~cm}$. The depth-density trend from this pit was applied to other pits from the same plot. Soils were collected and processed following the methods Quesada et al. (2010). An average SOC stock (in $\mathrm{tC} \mathrm{km}^{-2}$ ) for each plot was determined from the mean of individual pit SOC stocks (Fig. 7a; Table S3).

Compared to previously published SOC data for this region, this data set is the most complete, encompassing more pits per plot and considering the full soil depth. Prior studies have considered the SOC stock over a uniform $0-30 \mathrm{~cm}$ depth (e.g. Girardin et al., 2014a) or considered separate horizons to a depth of $50 \mathrm{~cm}$ (Zimmermann et al., 2009). Our soil $\mathrm{C}$ stock values are a factor of 1.2 to 1.7 higher than values reported in these previous studies (Girardin et al., 2014a; Zimmermann et al., 2009). For the same soil pit data (i.e. density and \%C) used in this study, calculation of soil C stocks over depths equivalent to those used in the prior studies (i.e. over the top 0-30 and 0-50 cm) yields values in close agreement with those previously reported (see Supplement Fig. S1). This consistency indicates that the differences between the full-depth values used here, versus the partial depth values reported previously, are attributable predominantly to the integration depth used.

We use the SOC stock data to estimate the amount of soil carbon removed by landslides. These data may provide an upper estimate of the total amount of organic carbon derived from recently photosynthesised biomass (i.e. "biospheric organic carbon"), partly because of the presence of carbonate $\mathrm{C}$ and rock-derived organic carbon which is present in the catchment (Clark et al., 2013). However, the contribution from these non-biospheric components is expected to be small given the relatively low content of each compared to biospheric \% OC, typically at concentrations of many percent. Additional bias may arise from the location of plots within the catchment, specifically with respect to topographic position (Marvin et al., 2014). The mean plot slopes range from 20 to $38^{\circ}$, as measured from the $3 \mathrm{~m} \times 3 \mathrm{~m} \mathrm{CAO}$ DEM, so these sites capture a large slope range but are at the lower slope end of the slopes found throughout the Kosñipata catchment (mean catchment slope of $38^{\circ}$ ). Data on SOC stocks collected from a wide range in slopes at high elevations (near the tree line) in the region of the Kosñipata Valley suggest there is no evident slope dependence that would be likely to strongly bias our results (see Supplement Fig. S2; Gibbon et al., 2010).

\subsubsection{Calculating fluxes of carbon stripped from hillslopes by landslides}

Carbon stocks for soil, above-ground living biomass, and roots were calculated for elevation bands of $300 \mathrm{~m}$, based on the relationships in Table 1. Landslide carbon flux $\left(\mathrm{tC} \mathrm{yr}^{-1}\right)$ was determined by multiplying the landslide rate in each elevation band $\left(\% \mathrm{yr}^{-1}\right)$ by soil, above-ground living biomass, 

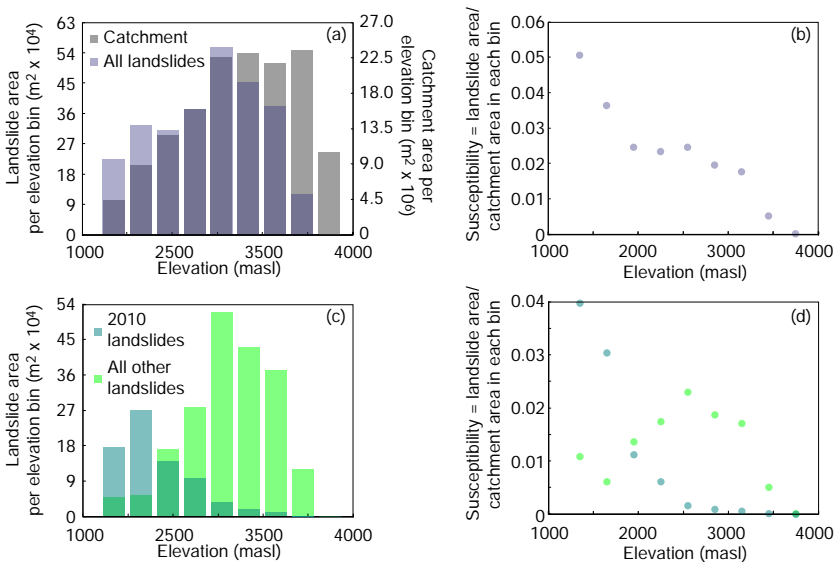

Figure 5. Histograms of catchment and landslide areas by elevation bins of $300 \mathrm{~m}$. (a) All landslides in the 25-year data set. (c) Separating landslides occurring during 2010, associated with the large storm in March 2010, from those in the rest of the data set. (b, d) Corresponding calculation of landslide susceptibility, calculated as the area of landslides within each bin divided by the total visible area in the Landsat images used for mapping.

and root carbon stocks $\left(\mathrm{tC} \mathrm{km}^{-2}\right)$ in the respective elevation band. We propagated the error on the elevation trends (from Fig. 7 and Table 1) to estimate uncertainty on the landslideassociated carbon flux by Gaussian error propagation. The landslide $\mathrm{C}$ yield $\left(\mathrm{tC} \mathrm{km}^{-2} \mathrm{yr}^{-1}\right)$ was calculated by summing all $300 \mathrm{~m}$ elevation bands and normalising by the nonshadow catchment area $\left(143 \mathrm{~km}^{2}\right)$.

The calculations assume that landslides strip all aboveground, root biomass, and soil material from hillslopes. This assumption is supported by field observations from the Kosñipata Valley that landslides are cleared of visible vegetation and roots and are typically bedrock failures that remove the entire mobile soil layer. To test this latter assumption, we used geometric scaling relationships for landslides in mountainous terrain (Larsen et al., 2010) to estimate landslide depths. We calculated landslide volume from the area (A)-volume $(V)$ relationship, $V=\alpha A^{\gamma}$, where $\alpha$ and $\gamma$ are scaling parameters (we used $\alpha=0.146$ and $\gamma=1.332$, from the compilation of global landslides in Larsen et al., 2010, but also tested other literature values). We estimated average depth by dividing volume for each landslide by the respective landslide area.

\subsection{Landslide revegetation}

We classified landslides as being "revegetated" when they were dominated by a closed forest canopy to an extent that we could no longer visually distinguish the landslide scar or bare ground in $2 \mathrm{~m}$-resolution WorldView-2 imagery (Blodgett and Isacks, 2007). We determined the fraction of area of the landslides occurring in each year (beginning in 1988) that was no longer visible as of 2011, the year with the latest
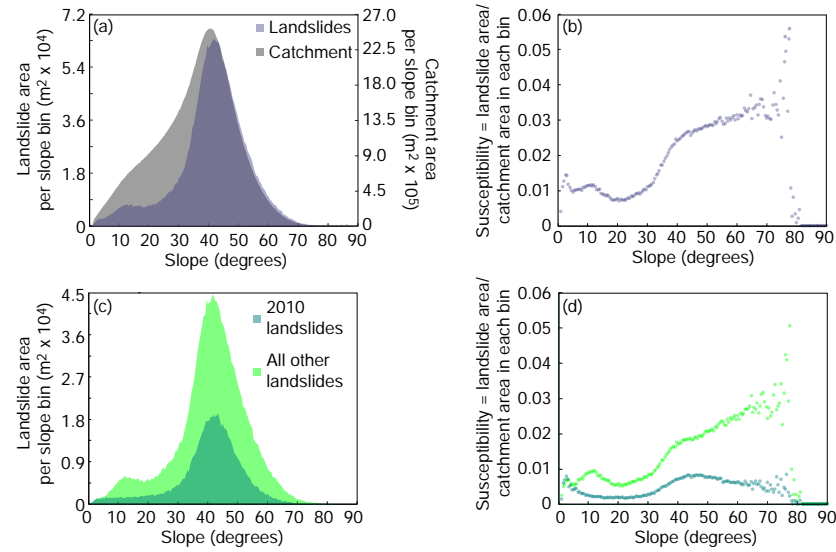

Figure 6. Histograms of catchment and landslide areas by slope bins of $1^{\circ}$. (a) All landslides in the 25-year data set. (c) Separating landslides occurring during 2010, associated with the large storm in March 2010, from those in the rest of the data set. (b, d) Corresponding calculation of landslide susceptibility, calculated as the area of landslides within each bin divided by the total visible area in the Landsat images used for mapping.

high-resolution image (Fig. 8). Some landslides were revegetated as soon as 4 years after occurrence. For landslide years prior to 2008, i.e. all landslide years with some observable recovery, we ran a linear regression between landslide area revegetated (specifically, area of fully revegetated landslides from a given year as a percent of total landslide area from that year) and the number of years that had passed since landslide occurrence (the difference between the given year and 2011). This analysis used a total of 18 data points, one for each year between 1988 and 2007 except for 2 years that had no measured landslides (Fig. 8; Table S2).

The metric of visible revegetation that we use in this study provides a measurable index for assessing ecosystem recovery from remote imagery. However, it does not necessarily mean complete replenishment of above-ground carbon stocks or regrowth of all vegetation to the extent present prior to landslide removal. It is also likely to take longer than this time for replenishment of soil carbon stocks to pre-landslide values (Restrepo et al., 2009).

\subsection{Topographic analysis}

We used two DEMs for topographic analysis. Slope angles and elevation statistics within the Kosñipata catchment study area were calculated from the $3 \mathrm{~m} \times 3 \mathrm{~m}$ CAO lidar-based DEM (see Appendix A). For river channel analysis within the Kosñipata Valley and for all topographic analyses in the wider Madre de Dios region, we used a $30 \mathrm{~m}$ resolution SRTM-derived DEM (Farr et al., 2007) with holes patched using the ASTER GDEM (METI/NASA, 2009). We were not able to use the higher-resolution CAO DEM for these calculations because it did not extend beyond the Kosñipata 


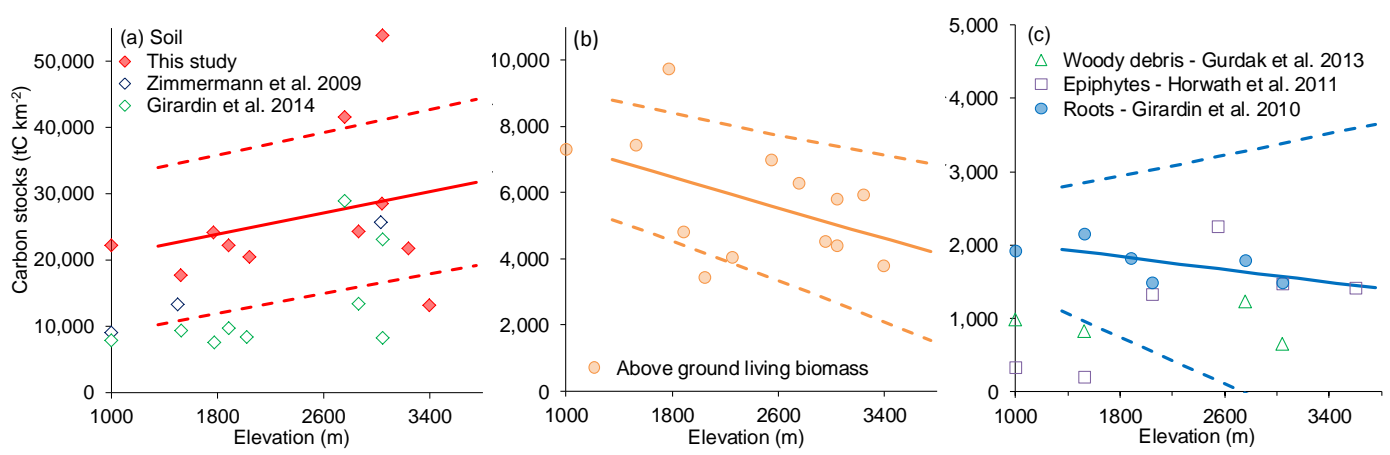

Figure 7. Soil and vegetation carbon stocks $\left(\mathrm{tC} \mathrm{km}^{-2}\right)$ as a function of elevation for the tropical montane forest of Kosñipata Valley, in the eastern Andes of Peru (Girardin et al., 2014a; Gurdak et al., 2014; Horwath, 2011; Girardin et al., 2010; Zimmermann et al., 2009). Linear regressions generated from available carbon stock data $\left(\mathrm{tC} \mathrm{km}^{-2}\right)$ from the Kosñipata Valley for (a) soil carbon stocks (red diamonds only; see Fig. S1 and Sect. 3.3.2 comparing the soil data with other data sets), (b) above-ground living biomass, and (c) root biomass (Table 1). (c) Woody debris and epiphytes are shown for reference.

catchment study area and contained gaps that made complete flow-routing calculations problematic.

The dependence of calculated slope on grid resolution (Lin et al., 2008; Blodgett and Isacks, 2007; Zhang and Montgomery, 1994) means that reported slope values inherently differ between the DEMs used in this study, and when compared to values from the $90 \mathrm{~m} \times 90 \mathrm{~m}$ SRTM-derived DEM (cf. Clark et al., 2013). In this study, we only compare results internally between values calculated from the same DEM.

\section{Results}

\subsection{Landslide rates and role of a large rain storm in 2010}

Approximately $2 \%\left(2.8 \mathrm{~km}^{2}\right)$ of the visible Kosñipata Valley study area experienced landslides over the 25-year study period. This percentage of landslide area is similar to landslide coverage in the Ecuadorian and Bolivian Andes (Blodgett and Isacks, 2007; Stoyan, 2000). Of the total landslide area in the catchment, $97.1 \%$ was in the forested portion and the remaining $2.9 \%$ in the puna.

The mean valley-wide landslide rates were $0.076 \% \mathrm{yr}^{-1}$, when averaged across $1 \times 1 \mathrm{~km}$ grid cells. Rates ranged from no landslides detected to $0.85 \% \mathrm{yr}^{-1}$ for individual grid cells (Fig. 2b). The average landslide rate corresponds to average hillslope turnover time of $\sim 1320$ years for the valley (Fig. 2c). Values reported provide a minimum constraint on landslide rate and a maximum constraint on turnover time, since small landslides and landslides under topographic shadow were excluded (see Sect. 3.1). The landslide hillslope turnover time in the Kosñipata Valley is similar to the landslide hillslope turnover time observed in the Waitangitaona Basin of New Zealand, but is 2.3 times faster than the mean landscape-scale landslide hillslope turnover in the western Southern Alps of New Zealand (Hilton et al., 2011) and in Guatemala (Restrepo and Alvarez, 2006) and 24 times faster than in Mexico and in Central America (Restrepo and Alvarez, 2006).

A single large-magnitude rainfall event on 4 March 2010 triggered $27 \%$ of all of the landslide area observed during the 25 -year study period in the Kosñipata study catchment. Rainfall during this storm peaked at $94 \mathrm{~mm} \mathrm{~h}^{-1}$, with $\sim 200 \mathrm{~mm}$ falling in $4 \mathrm{~h}$, recorded by a meteorology station at $1350 \mathrm{~m}$ elevation within the catchment (Fig. 9). The storm accounted for $\sim 185$ landslides with $0.75 \mathrm{~km}^{2}$ cumulative area. The annual total landslide area for 2010 was consequently much higher than for any other year in the data set (Fig. 3).

\subsection{Spatial patterns of landslides}

The histogram of catchment area in the Kosñipata catchment shows a skewed distribution with respect to elevation, with greater area at lower elevations (Fig. 5a). The histogram of landslide area is shifted to lower elevations compared to the catchment area distribution and shows a bimodality. The 2010 landslides occurred almost exclusively at low elevations, below $\sim 2600 \mathrm{~m}$ (Fig. 5c). Although the remaining landslides over the 25-year study period located at low elevations relative to the catchment, they were at higher elevations than the 2010 landslides. The bimodality of the overall landslide distribution emerges from the addition of the two nearly distinct distributions (Fig. 5c). Because of the small catchment area at low elevations, overall landslide susceptibility is highest at the low elevations (particularly $<\sim 1800 \mathrm{~m}$; Fig. 5b). When excluding the 2010 landslides, the high susceptibility at low elevations is not evident, and the only clear trend is the very low landslide susceptibility at the highest elevations (> $3500 \mathrm{~m}$; Fig. 5d). Since our mapping did not distinguish landslide scars from deposits (see Sect. 3.1), systematic changes in the ratio of scar to deposit area with elevation could influence apparent patterns of landslide occurrence. For example, larger deposit areas at low elevation would increase calculated susceptibility even if the total landslide scar 


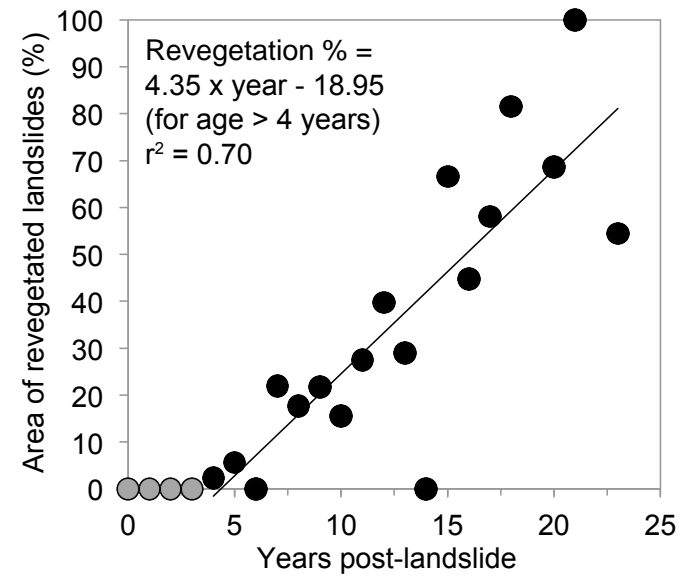

Figure 8. Landslide revegetation time as percent area recovered by 2011, evaluated from a WorldView-2 pan-sharpened satellite image at $2 \mathrm{~m} \times 2 \mathrm{~m}$ resolution. Each data point represents the landslides from a single year during the study period (black and grey circles; $n=23$ ). Landslides occurring at least 4 years prior to 2011 (black circles) were used to calculate the best fit (area of revegetated landslides $(\%)=4.351 \pm 0.719 \times$ year of landslide origin prior to 2011 $-18.953 \pm 9.974)$, where the mean estimated time for $100 \%$ revegetation of all the landslides of a given year is $27 \pm 8$ years $\left(r^{2}=0.7\right.$, $n=18, p<0.0001)$.
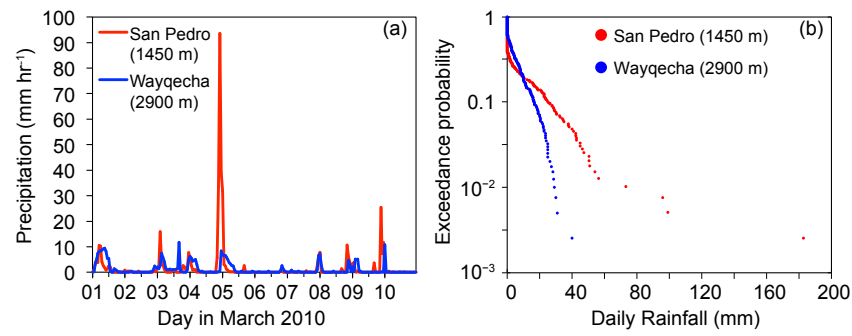

Figure 9. (a) Precipitation during the March 2010 storm in the Kosñipata Valley at two stations, one at high elevation (Wayqecha plot, $2900 \mathrm{~m}$ ), where storm precipitation was low, and another at low elevations (San Pedro, $1450 \mathrm{~m}$; Clark et al., 2014; ACCA, 2012), where precipitation was high and where occurrence of stormtriggered landslides was also high (e.g. Fig. 5c). (b) Magnitudefrequency analysis of precipitation over multiple years at the two stations shown in (a), demonstrating that the low elevations in the Kosñipata study catchment are generally characterised by more low-frequency, high-magnitude precipitation events.

area were not larger, though we have no direct evidence to suggest that this is the case.

The catchment area has a mean slope of $38^{\circ}$ (calculated from the CAO DEM) and is skewed to lower slopes (Figs. 2d, 6a). The distribution of landslide areas is shifted to slightly higher slopes compared to catchment area and lacks the broad abundance at slopes $<30^{\circ}$. The 2010 landslides show a similar distribution with respect to slope as the landslides from all other years (Fig. 6c). In all cases, landslide suscep- tibility increases sharply for slopes $>30-40^{\circ}$ (Fig. 6d). All of the landslide data include areas at low slopes, which we interpret as artefacts related to landslide deposits residing in valley bottoms, since our mapping routines did not distinguish scars from deposits.

\subsection{Catchment topographic characteristics}

The Kosñipata catchment is characterised by a prominent vertical step knickpoint between approximately 1600 and $1400 \mathrm{~m}$ elevation (Fig. 10a). This knickpoint marks an inflection in the relationship between upstream drainage area and the slope of the river channel, characteristic of the transition from colluvial to bedrock or alluvial channels in mountainous settings (Whipple, 2004; Montgomery and Buffington, 1997), although we recognise that processes such as debrisflow incision may also influence the form of these relations (Stock and Dietrich, 2003). We used flow routing to separate the catchment into those slopes that drain into the river system upstream of this transition zone (as defined by the elevation at the top of the vertical step knickpoint) and those slopes that drain into the river system downstream of the transition (Fig. 10b). Hillslope angles are, on average, steeper downstream of the transition than upstream, and the distribution of slope angles downstream lacks the prominent bulge at relatively low slopes that is observed upstream of the transition. The general features observed in the Kosñipata study catchment, specifically the transition in the slope-area curves and the related shift in hillslope angles, also generally characterise the other major rivers draining from the eastern flank of the Andes in the Alto Madre de Dios river basin (Fig. 11).

\subsection{Catchment-scale carbon stocks and stripping of carbon by landslides}

The estimated catchment-scale carbon stock for the Kosñipata Valley is $\sim 34670 \pm 4545 \mathrm{tC} \mathrm{km}^{-2}$, with $\sim 27680 \pm 4420 \mathrm{tC} \mathrm{km}^{-2}$ in soil and $\sim 5370 \pm 840 \mathrm{tC} \mathrm{km}^{-2}$ in vegetation (Fig. 7). We estimate that epiphyte (Horwath, 2011) and woody debris (Gurdak et al., 2014) biomass adds an additional $<\sim 8 \%$ of carbon $(<5 \%$ from epiphytes and $<3 \%$ from woody debris; Fig. 7c). Overall, the vegetation carbon stock values from the Kosñipata Valley are slightly lower than lowland tropical forests, and the soil values higher (Dixon et al., 1994), which is consistent with broad trends in the tropics in which soil carbon stocks increase with elevation and are frequently greater than vegetation carbon stocks (Gibbon et al., 2010; Raich et al., 2006).

Averaged over the 25 -year duration across the $143 \mathrm{~km}^{2}$ non-shadowed catchment area, the estimated total flux of carbon stripped from hillslopes by landslides was $3700 \pm 510 \mathrm{tC} \mathrm{yr}^{-1}$, with $2880 \pm 500 \mathrm{tC} \mathrm{yr}^{-1}$ derived from soil and $820 \pm 110 \mathrm{tC} \mathrm{yr}^{-1}$ from vegetation (Fig. 12a). In terms of area-normalised yield of carbon, landslides stripped $26 \pm 4 \mathrm{tC} \mathrm{km}^{-2} \mathrm{yr}^{-1}$ from hill- 

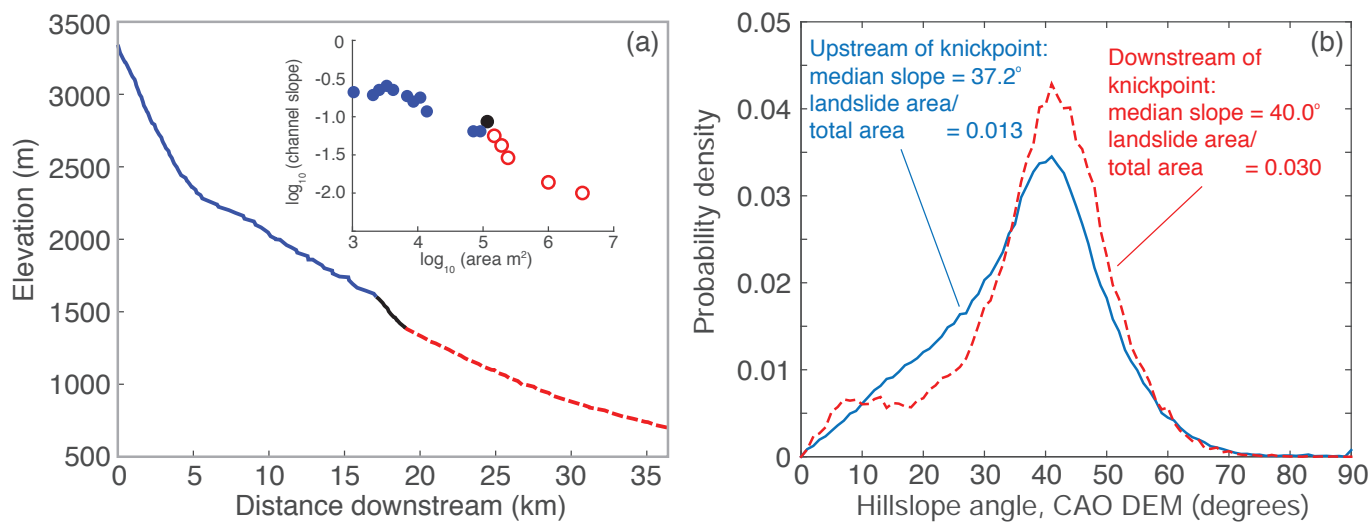

Figure 10. (a) Longitudinal profile along the Kosñipata river channel, with a prominent vertical step knickpoint corresponding to (inset) a transition in the plot between channel slope and upstream contributing area, calculated following Moon et al. (2011). (b) Distribution of hillslope angles (from $3 \mathrm{~m} \times 3 \mathrm{~m}$ CAO DEM) upstream and downstream of the morphological transition in the channel, along with median hillslope angles in each region and landslide susceptibility over the 25 -year study period.

Table 2. Valley-wide landslide stripped organic carbon $\left(\mathrm{tC} \mathrm{km}^{-2} \mathrm{yr}^{-1}\right)$.

\begin{tabular}{lrrr}
\hline & 1988 to 2012 & Without 2010 & 2010 \\
\hline Total & $25.8 \pm 3.6$ & $19.1 \pm 3.0$ & $6.8 \pm 1.2$ \\
Soil & $20.1 \pm 3.5$ & $15.1 \pm 2.9$ & $5.0 \pm 1.2$ \\
Vegetation & $5.7 \pm 0.8$ & $4.0 \pm 0.7$ & $1.7 \pm 0.2$ \\
\hline
\end{tabular}

slopes, with $20 \pm 3 \mathrm{tC} \mathrm{km}^{-2} \mathrm{yr}^{-1}$ derived from soil and $5.7 \pm 0.8 \mathrm{tC} \mathrm{km}^{-2} \mathrm{yr}^{-1}$ from vegetation (Table 2; Fig. 12b). These values may underestimate total catchment-wide fluxes because our landslide mapping process missed a proportion of small, numerous landslides (see Fig. 4, Sect. 3.1).

On the other hand, our values may overestimate fluxes from SOC if landslides are shallower than soil depths, since we have assumed complete stripping of soil material to full soil depth and since SOC stocks depend on depth of integration (see Sect. 3.3, above). The deepest average soil depths observed in the plots used in this study were $1.58 \mathrm{~m}$ (Table S3). Using average scaling parameters for global landslides (Larsen et al., 2010), only 99 landslides in our inventory, equating to $0.06 \mathrm{~km}^{2}$ total landslide area (or $\sim 2 \%$ of total landslide area), would be shallower than these deepest soils at $1.58 \mathrm{~m}$. Using scaling parameters for bedrock landslides only ( $\alpha=0.146$ and $\gamma=1.332$; Larsen et al., 2010) results in only one landslide shallower than $1.58 \mathrm{~m}$. This analysis corroborates our field observations that most landslides in the Kosñipata Valley clear soil from hillslopes and expose bedrock. We thus view our calculation of fluxes on the basis of complete stripping of soil as providing a reasonable estimate.

Our calculation of landslide-associated carbon fluxes includes carbon that was previously residing both on landslide scars and in areas of landslide deposits. The fate of carbon from each of these areas may differ, but such differences are not well known, and we consider all to contribute to the loss of previously living biomass as a result of landslide occurrence. When considering carbon budgets at the landscape scale, the landslide-associated carbon fluxes we report here should also be viewed in the context that other processes such as soil creep may additionally contribute to the transfer of carbon from hillslopes to rivers (e.g. Yoo et al., 2005).

\section{Discussion}

\subsection{The geomorphic "work" of storm-triggered landslides in the Kosñipata Valley}

The March 2010 storm clearly stands out as the most significant landslide event that occurred during the duration of this study. We lack a precipitation record for the full 25-year study period, but it is probable that this storm was the largest single precipitation event during that time. Landslides triggered in 2010 account for $0.75 \mathrm{~km}^{2}$, or $27 \%$ of the total landslide area during the 25-year study period, and these landslides stripped $25500 \mathrm{tC}$ from hillslopes, equivalent to $26 \%$ of the total. The quantitative importance of this individual storm in our data set is consistent with observations of storm triggering of intense landslides elsewhere (Wohl and Ogden, 2013; Ramos Scharrón et al., 2012; West et al., 2011; Casagli et al., 2006).

The annual resolution of our observations of landslide rates in the Kosñipata Valley makes it possible to consider how the geomorphic work done in this relatively infrequent but high-magnitude event compares to the work done in smaller but more frequent events. Here we define geomorphic work, sensu Wolman and Miller (1960), as total landslide area, reflecting the removal of material from hillslopes (rather than, for example, the work done by landslides to modify slope angles). Across the 25-year data set, we es- 
timate the return time or recurrence interval, RI (i.e. how frequently a year of given total landslide magnitude would be expected to occur), as $\mathrm{RI}_{i}=(n+1) / m_{i}$, where $\mathrm{RI}_{i}$ is the return interval for the year with the $i$ th largest total annual landslide area, $n$ is the total length of the record ( 25 years in this study), and $m_{i}$ is the rank order of year $i$ within the data set in terms of total landslide area. Thus 2010, the year with most landslide area, has $\mathrm{RI}=26$ years, while years characterised by lower landslide area have more frequent inferred recurrence intervals. When the annual data for landslide area are plotted as a function of RI (Fig. 3b), 2010 is clearly at the highest magnitude, as a result of the March 2010 storm. Even so, the landslide area from 2010 still falls on an approximately linear (power law exponent $\sim 1$ ) trend coherent with the rest of the data set. We do not have high enough temporal resolution to analyse the effects of individual storms in detail, as would be preferred for a robust recurrence interval analysis. Nonetheless, the linearity of the relationship for annual landslide areas suggests that even as the frequency of large storm events in the Kosñipata Valley decreases, the landslide area associated with these events may increase commensurately, such that the effects compensate.

We can further explore the amount of work done, again in terms of landslide area, by the cumulative effect of repeated events of small magnitude versus occasional events of larger magnitude. This analysis allows us to consider the relative importance of years with varying landslide area (cf. Wolman and Miller, 1960). In other words, does a year like 2010 , characterised by very high landslide magnitude, occur often enough that these years dominate the long-term landslide record? Or do such years occur so rarely that, despite their high magnitude, they have little effect over the long term? We calculate the percent work done for a year with a given recurrence interval as $W_{i}=\left(A_{i} / \Sigma A\right) / \mathrm{RI}_{i} \times 100$, where $A_{i}$ is the landslide area in year $i$ and $\Sigma A$ is the total landslide area in the full data set. If $W_{i}$ is high for a given year relative to other years, then this year is expected to have a disproportionately large effect on the long-term record, and vice versa. When our calculated $W_{i}$ is plotted versus $\mathrm{RI}_{i}$ (Fig. 3c), we find the relatively similar values of $\mathrm{W}$ despite large differences in landslide area (e.g. consider the very high $\Sigma A$ in 2010) reflect the compensating effect of frequency and magnitude. Thus we expect that the long-term total landslide area resulting from years characterised by storm activity of varying magnitude is, on average, very similar in this setting. In other words, the landslide work done in years with rare, large storms is more or less similar to the sum of the total integrated work done in those years with smaller but more frequent storms.

Many previous studies of storm-triggered landslides have focused specifically on individual storm events (e.g. Wohl and Ogden, 2013; Ramos Scharrón et al., 2012; West et al., 2011) and lacked such longer-term context, although several studies on storm triggers of landslides have been concerned with identifying threshold storm intensities for failure (e.g.
Guzzetti et al., 2007; Glade, 1998; Larsen and Simon, 1993). Our results suggest that small storms may be equally important as larger storms for triggering landslides over the long term, at least at the Kosñipata study site. Time series with higher temporal resolution associated with individual storm events of varying magnitude rather than annual total landslide areas as used in this study would provide a test of the inferences made here, and analyses similar to that in this study for storm-triggered landslides in other settings would help shed more light on how storms contribute to erosional processes in mountain landscapes. Nonetheless, we note that even though the total work done by large magnitude storms may not exceed that done by smaller events over the long term, the immediacy of large storm effects may be important from the perspectives of hazards, fluvial impacts, and biogeochemical processes. For example, large events will supply large amounts of clastic sediment (Wang et al., 2015) and organic material (West et al., 2011) in a short space of time.

\subsection{Spatial patterns of landslide activity \\ 5.2.1 Spatial patterns and their relation to the 2010 storm}

Spatial and temporal patterns of landslides depend on proximal triggers such as rainfall and seismic activity (Lin et al., 2008; Meunier et al., 2008; Densmore and Hovius, 2000), as well as on geomorphic preconditions, such as bedrock strength and slope angle, the latter of which is at least in part regulated by fluvial incision by rivers (Larsen and Montgomery, 2012; Bussmann et al., 2008; Lin et al., 2008). The observation of highest landslide susceptibility in the Kosñipata Valley at highest slopes in the catchment reflects the importance of slope angle for landslide failure. The notable shift from low to high landslide susceptibility above 30 $40^{\circ}$ (Fig. 6b) is consistent with the hillslope angles that reflect rock strength expected for the metamorphic and plutonic bedrock (Larsen and Montgomery, 2012). Generally, the greater overall landslide susceptibility at the lower elevations in the Kosñipata Valley is consistent with the higher slope angles at these elevations (Figs. 2, 5, 10b). This set of observations is consistent with predictions of a threshold hillslope model (Gallen et al., 2015; Roering et al., 2015; Larsen and Montgomery, 2012).

In more detail, the distribution of landslides with respect to elevation in the Kosñipata Valley is complicated by clustering of the 2010 storm-triggered landslides at low elevations. This clustering may be explained at least in part by the focused intensity of the 2010 storm precipitation at low elevations; much lower rainfall was recorded on 4 March at a meteorology station at $2900 \mathrm{~m}$ elevation in the Kosñipata Valley (at the Wayqecha forest plot) compared to the San Pedro meteorological station at $1450 \mathrm{~m}$ elevation (Fig. 9a). Although the single 2010 event may not contribute more to the development of long-term landslide area than the cumula- 
tive effect of smaller events (see above), the landslides from this one specific event do significantly influence the overall spatial distribution of landslides visible in present-day imagery. One implication of this observation is that landslide maps based on all visible landslides at any one point in time, assuming uniform rates of occurrence, may overlook the role of specific proximal triggering events that lead to spatial clustering. Such event clustering may influence inferred relationships between landslides and controlling factors such as regional precipitation gradients or patterns of uplift, emphasising that the time sequence of landslide occurrence may be important to accurately assess such relationships.

\subsubsection{Storm triggered landslides at low elevations: stochastic happenstance or characteristic of long-term erosional patterns?}

The elevation distribution of landslides in the 2010 storm is clearly distinct from the background landslide activity during the 25-year study period. This difference raises an important question: are the 2010 landslides representative of a distinct spatial pattern associated with larger storm events? Or are the spatial locations of these landslides reflective of one stochastic storm event that happened to be captured in our analysis and is part of a series of events that shift in location throughout the catchment over time? We cannot distinguish these possibilities conclusively, but we do have some evidence that allows for preliminary inferences that could be tested with further work. Two lines of evidence suggest that the focusing of storm-triggered landslides at low elevations in the Kosñipata study catchment may be characteristic of long-term spatial patterns in which routine landslides occur throughout the catchment while rarer, intense landslide events selectively affect the lower elevations.

The first line of evidence is that the magnitude-frequency statistics for precipitation indicate that low-frequency events of high magnitude (i.e. relatively infrequent but large storms) are more characteristic at low-elevation sites compared to high elevations (Fig. 9b). This statistical tendency toward more storm activity at low elevations would provide a mechanism for regular storm-triggering of landslides at these elevations.

A second set of information comes from the Kosñipata Valley topography and its relation to implied erosion associated with landslide activity. Although total landslide area in our Kosñipata data set is greatest at mid-elevations, these mid-elevation landslides are distributed over a relatively large catchment area (Fig. 5a). Effective landslide erosion is greatest where landslide susceptibility on a unit-area basis is highest (Fig. 5b), so our inventory implies focused landslide erosion at lower elevations $(<\sim 1500-2000 \mathrm{~m})$ in the Kosñipata Valley, specifically associated with the 2010 storm (Figs. 2a, 5). This focused erosion appears to spatially coincide with the observed transition in the river channel profile at $\sim 1700 \mathrm{~m}$ elevation, marked by the vertical step knickpoint
(Fig. 10a). In the Kosñipata Valley, this transition occurs near a lithological change from sedimentary to plutonic bedrock. However, as best known, the lithological contact does not exactly coincide spatially with the knickpoint, and the other principal rivers in the region are also characterised by similar transitions in channel morphology even though they do not have the same lithological transition, suggesting that lithology is not the primary control on the observed transition in channel morphology (Fig. 11).

Several other processes can generate knickpoints in river profiles (e.g. Whipple, 2001). The topographic transition in the Kosñipata and in neighbouring catchments appears to approximately coincide with changes in precipitation regime, and specifically with less cloud cover and greater storm occurrence below the level of most persistent annual cloud cover in the Andean mid-elevations (cf. Espinoza et al., 2015 and Rohrmann et al., 2014, for the southern central Andes). By increasing erosional efficiency, this climatic transition may at least in part contribute to generating the observed channel profile. Other effects may also be important, for example the transient upstream propagation of erosion driven by past changes in uplift, as proposed for the eastern Andes in Bolivia (Whipple and Gasparini, 2014), or unidentified geologic structures in the Alto Madre de Dios region. These possibilities are discussed further below.

Whatever the underlying cause, hillslope angles downstream of the transitions in channel morphology are generally steeper than those upstream (Figs. 10b and 11c), consistent with the downstream slopes being more prone to landslide failure over the long term. The total area of landslides triggered on low-elevation slopes in 2010 does not exceed the accumulated landslide area in the rest of the catchment over the longer term (see discussion of magnitude-frequency above, and histograms of landslide area in Fig. 5a). Nonetheless, these low-elevation landslides are concentrated in a smaller area (Fig. 5b) and therefore represent higher landslide susceptibility, greater rates of landscape lowering, and more frequent hillslope turnover.

Based on the consistency of catchment topography with the landslide distribution that includes 2010 storm-triggered landslides, we speculate that the high rates of landslide erosion at low elevations in the Kosñipata catchment are characteristic of long-term erosional patterns. This hypothesis could be tested by complementing the landslide analysis presented in this study with measurements of long-term denudation rates in small tributary basins of the Kosñipata Valley above and below the apparent morphologic transition. Although we acknowledge that we currently lack such supporting independent evidence, in the following sections we include consideration of some of the possible implications of our hypothesised transition towards higher landslide occurrence at lower elevations in the Kosñipata Valley. 


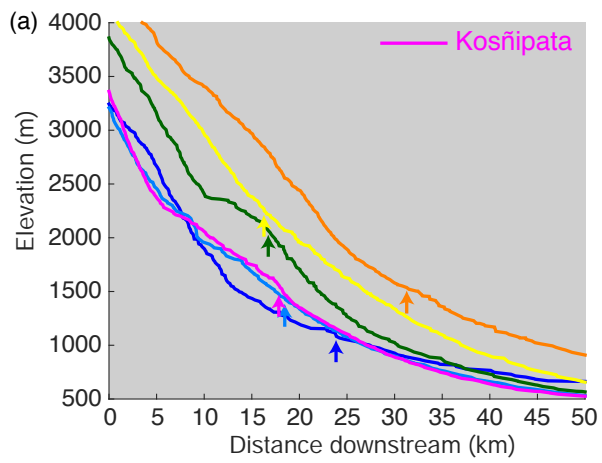

(b)
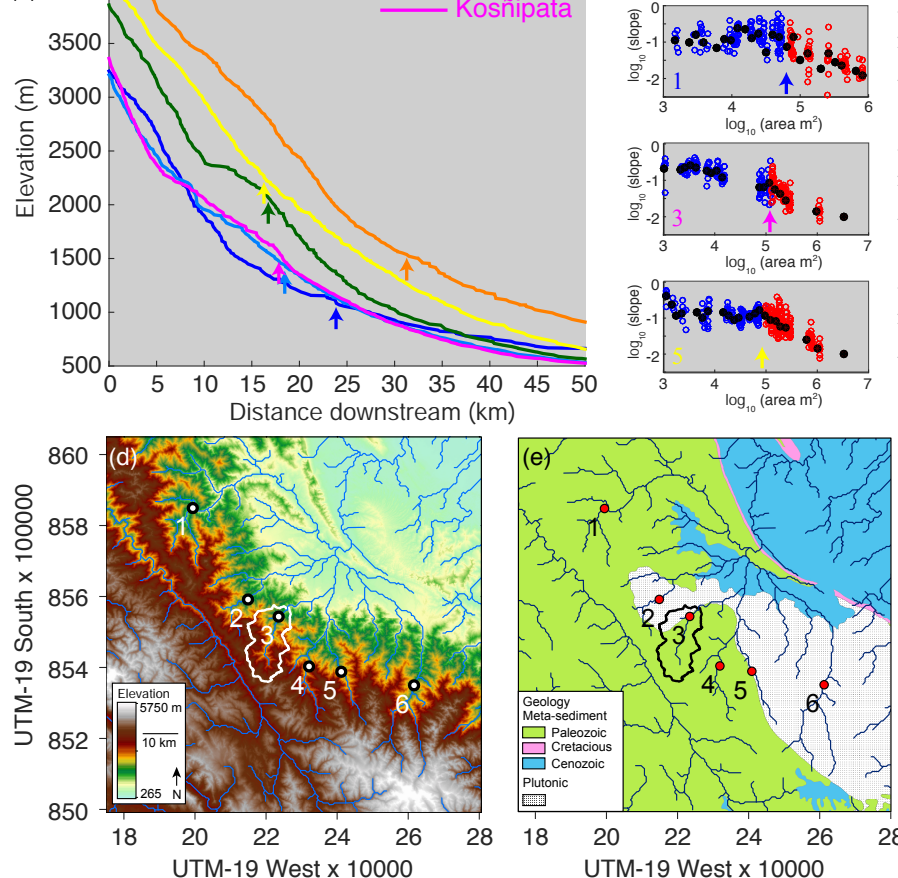

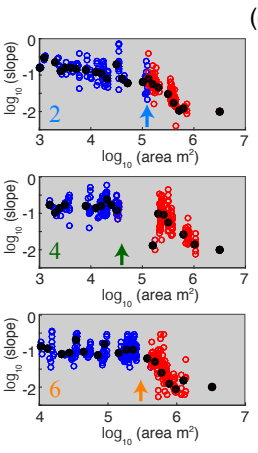

(c)
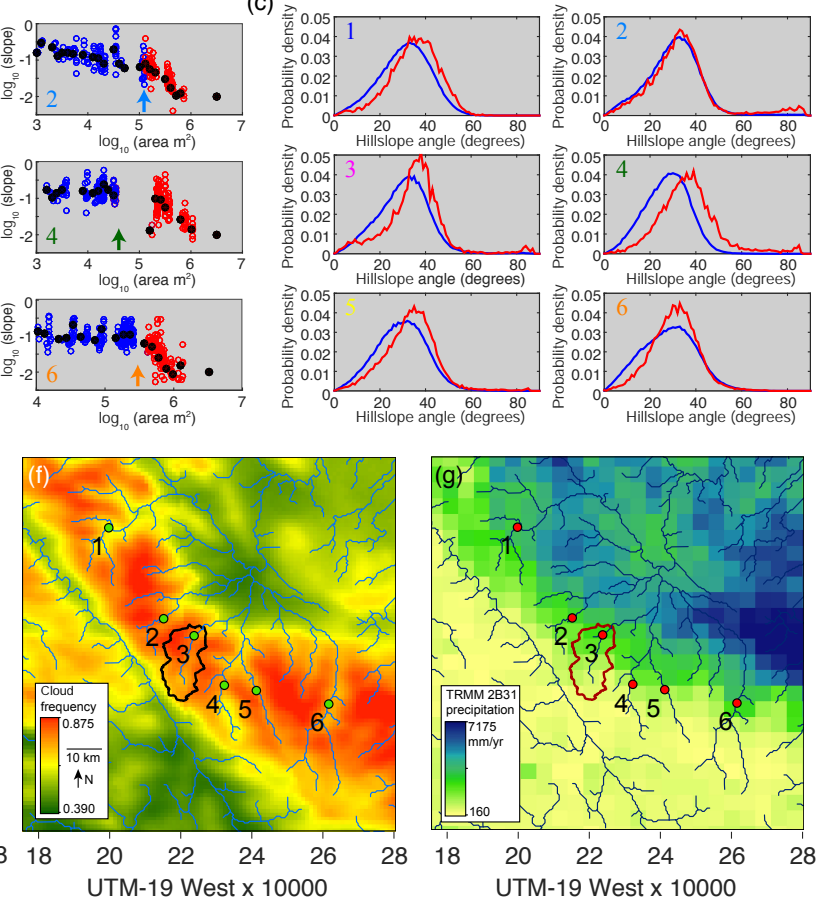

Figure 11. (a-c) Analysis of river profiles analogous to those in Fig. 10 (shown here as river 3, in pink), for rivers throughout the Alto Madre de Dios region (d). In (b), data are binned by upstream area and means are shown by black circles. Arrows in (a) refer to locations along the profile of observed transition in the area-slope plots (b). In (c), hillslope angles (from STRM DEM) are grouped by upstream (blue) and downstream (red) of this transition. Transition locations are displayed as dots in (d-g), which show regional elevation (Farr et al., 2007; d), geology (INGEMMET, 2013; e), MODIS cloud frequency (Halladay et al., 2012; f), and TRMM 2B31 annual precipitation (Bookhagen, 2013; g).

\subsection{Landslide-driven erosion and regional topography}

In general terms, high-elevation, low-slope surfaces, such as those that characterise the upper portions of the Kosñipata Valley, are thought to have a number of possible origins, including (i) the uplift and preservation of previously low-lying "relict" surfaces (e.g. Clark et al., 2006), (ii) glacial "buzzsaw" levelling of surfaces near the glacial equilibrium line altitude (Brozović et al., 1997), (iii) erosion of rocks with contrasting strength (e.g. Oskin and Burbank, 2005), and (iv) in situ generation through river system reorganisation over time (Yang et al., 2015). There is no evidence for a glacial or lithological cause for low-relief parts of the Kosñipata Valley and the immediately adjacent portions of the Andean Plateau, suggesting either a relict origin or in situ fluvial formation. Similar high-elevation, low-relief surfaces south of our study region, along the eastern flank of the Andes in Bolivia, have been proposed as relict landscapes uplifted in the past 10-12 Myr (Whipple and Gasparini, 2014; Barke and Lamb, 2006; Gubbels et al., 1993). By this interpretation, erosion into the eastern Andean margins has generated escarpments but not yet erased the original surfaces (Whipple and Gasparini, 2014).
From landslide mapping in the Kosñipata Valley, we infer higher hillslope erosion rates at lower elevations and particularly downstream of the knickpoint in this catchment. Even when ignoring the very low-elevation landslides associated with the 2010 storm in our data set, the occurrence of landslides throughout the 25 -year study period is notably shifted to lower elevations compared to the Kosñipata catchment area (Fig. 5c). This pattern emphasises that erosion rates are low at the highest elevations, where slopes are also lower presumably because incision is less pronounced. If our observed landslide rates reflect long-term erosion, these observations are consistent with the idea that the low slopes at high elevations in this region of the Andes are preserved because propagation of more rapid erosion at low elevations has not yet reached the low-slope parts of the landscape. But, based on the distribution of landslide erosion alone, we cannot distinguish whether the low slope regions have their origin as relict landscapes or features resulting from fluvial reorganisation.

The importance of storm triggering for setting the spatial patterns of landslide activity in the Kosñipata Valley suggests that greater storm frequency (e.g. Fig. 9b) could be an important mechanism facilitating higher erosion rates at low elevations in this catchment, consistent with climate variability being a major erosional driver (DiBiase and Whip- 
ple, 2011; Lague et al., 2005). The indication of a mechanistic link between precipitation patterns and erosion in the Kosñipata catchment may provide clues about how climatic gradients leave an imprint on the topography of the eastern Andes (e.g. Strecker et al., 2007), potentially superimposed on tectonically controlled patterns of transient erosion into the uplifted mountain range (Gasparini and Whipple, 2014). Although previous studies have considered the role of gradients in precipitation magnitude across strike of the eastern Andes (e.g. Gasparini and Whipple, 2014; Lowman and Barros, 2014), we note that little work has considered the role of storm frequency, which our analysis suggests may be variable and important in setting erosion patterns in this region.

Based on our landslide data set and the precipitation statistics for the Kosñipata Valley, we speculate that the greater precipitation magnitude and frequency of large storm events below the cloud immersion zone in the eastern Andes of the Madre de Dios Basin work to facilitate a combination of hillslope failure, sediment removal, and river channel incision. Channel incision, facilitated by high storm runoff and the tools provided by landslide erosion (e.g. Crosby et al., 2007), increases hillslope angles, and landslide failure keeps pace, triggered by storm events such as the 2010 event observed in our data set. Focused, climatically controlled erosion at lower elevations along the eastern flank of the Andes in the Madre de Dios Basin could contribute to the preservation of relatively low-slope surfaces at high elevations: if rates of erosion in and above the cloud immersion zone are limited by decreased precipitation and particularly reduced storm frequency, the upstream propagation of erosion may be inhibited, reducing the potential for rivers to incise into the low slope regions in the high-elevation headwaters. This, in turn, may explain why rivers along the eastern flank of the Andes in Peru have not succeeded in eroding back into the Andean topography sufficiently to "capture" the flow of the Altiplano rivers (e.g. the tributaries of the Rio Urubamba that currently flow several hundred kilometres to the north via the Ucayali before cutting east through the Andes to join the Amazonas). Our results thus raise the possibility of a potential climatic mechanism for sustaining this topographic contrast and prolonging the persistence of the asymmetric morphology in this region of the Andes.

\subsection{Landslide transfer of organic carbon to rivers}

The $26 \pm 4 \mathrm{tC} \mathrm{km}^{-2} \mathrm{yr}^{-1}$ of organic carbon stripped from hillslope soil and vegetation during our study period reflects a significant catchment-scale carbon transfer (Stallard, 1998). The area-normalised landslide carbon yield in the Kosñipata Valley is similar to the upper end of values for other mountain sites around the world where analogous carbon fluxes have been evaluated. For example, in a region of Guatemala with a 20-year hurricane return time, landslide carbon yields were $33 \mathrm{tC} \mathrm{km}^{-2} \mathrm{yr}^{-1}$ (Ramos Scharrón et al., 2012), similar to our Kosñipata results. In the western Southern Alps of New Zealand, landslide carbon yields were $17 \pm 6 \mathrm{tC} \mathrm{km}^{-2} \mathrm{yr}^{-1}$ in catchments where landslide rates were highest, while the mean yield was much lower, at $\sim 8 \mathrm{tC} \mathrm{km}^{-2} \mathrm{yr}^{-1}$ (Hilton et al., 2011). In part, the high carbon flux we observe in the Kosñipata Valley reflects the high organic carbon stocks of soils in this catchment $\left(27680 \pm 4420 \mathrm{tC} \mathrm{km}^{-2}\right)$, larger than the mean estimated in the western Southern Alps $\left(18000 \pm 9000 \mathrm{tC} \mathrm{km}^{-2}\right.$; Hilton et al., 2011). The high flux can also be attributed to the high rates of landsliding driven by the combination of steep topography and intense precipitation events (and presumably on multi-centennial timescales by large earthquakes).

Following the recolonisation of landslide scars (Fig. 8), the fate of landslide-derived organic carbon governs whether erosion acts as a source or sink of carbon dioxide to the atmosphere (Ramos Scharrón et al., 2012; Hilton et al., 2011). Bedrock landslides may supply organic carbon to rivers at the same point in time and space as large amounts of clastic sediment are delivered from hillslopes (Hilton et al., 2011; Hovius et al., 1997). The association of organic matter with high mineral loads enhances its potential for sedimentary burial and longer-term sequestration of atmospheric carbon dioxide (Galy et al., 2015; Hilton et al., 2011). In contrast, oxidation of biospheric organic carbon eroded by landslides represents a poorly quantified source of $\mathrm{CO}_{2}$ for assessments of ecosystem carbon balance.

The extent to which landslides connect to river channels exerts a first-order control on the fate of landslide material (Dadson et al., 2004), and thus on the fate of carbon. We identified landslides as connected or unconnected to rivers by manually inspecting high-resolution imagery and following landslides to their termination (i.e. to their lowest elevation point). Connected landslides terminated in river channels, identifiable by the absence of vegetation. We found that, for the Kosñipata Valley during our study period, greater than $90 \%$ of landslides were directly connected with rivers, similar to the high connectivity found for other storm-triggered landslides (e.g. West et al., 2011). However, even with high connectivity, it remains uncertain in the case of the Kosñipata how much of the material stripped by landslides is actually removed by rivers and exported out of the valley.

While quantifying the onward fluvial transfer of organic carbon stripped by landslides and its fate in the Madre de Dios River and wider Amazon Basin is out of the scope of the present study, our observations provide baseline data for interpreting river flux measurements, as well as new insight into the role of landslides in the routing of organic carbon in mountain catchments. First, we note that the location of landslides within a catchment may influence whether the organic material eroded from hillslopes is transported by rivers (Hilton et al., 2008b). The observation that landslide erosion may be non-uniform thus has important implications for organic carbon fate. In lower-order streams, landslides may be less likely to connect to rivers (Ramos Scharrón et al., 2012), and rivers are less likely to have capacity to export material 

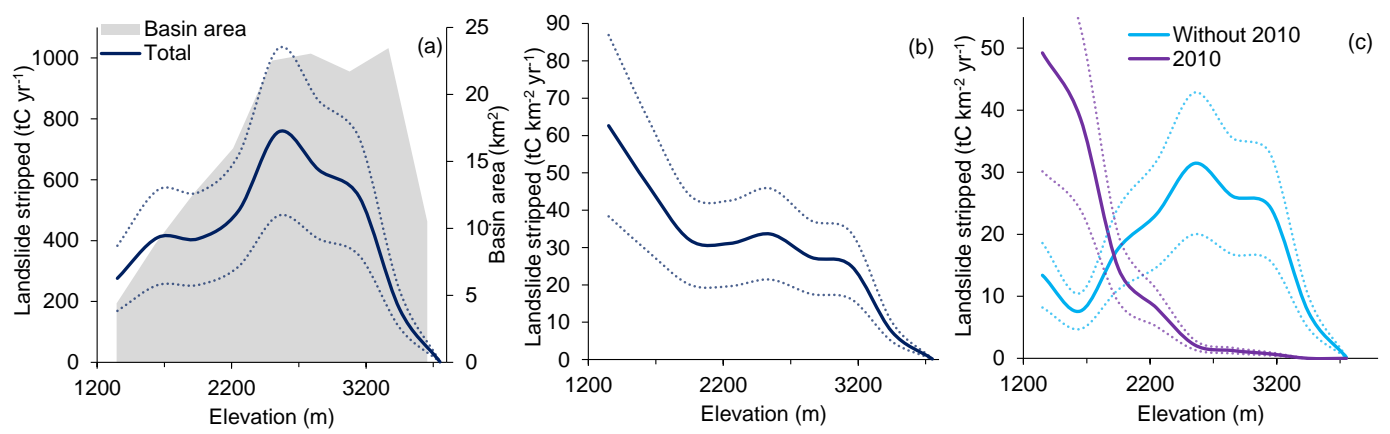

Figure 12. (a) Total (soil plus vegetation) mobilisation of organic carbon by landslides $\left(\mathrm{tC}^{-1} \mathrm{r}^{-1}\right.$ ) and (b) area-normalised mobilisation of organic carbon $\left(\mathrm{tC} \mathrm{km}^{-2} \mathrm{yr}^{-1}\right.$ ) over the altitudinal gradient divided into $300 \mathrm{~m}$ elevation bins (navy line; dotted lines show uncertainty). Landslide susceptibility is highest at low elevations, so the yield is highest there (b), but the total flux due to landslides is dominated by mid-elevations that comprise the majority of the basin area (a). (c) Separation of landslide-mobilised organic carbon ( $\left.\mathrm{tC} \mathrm{km}^{-2} \mathrm{yr}^{-1}\right) \mathrm{due}^{\mathrm{a}}$ the 2010 rain storm event from the remaining years as a function of elevation.

compared to higher-order streams. In the Kosñipata River, focused erosion of organic carbon occurs in the low/midelevations and is likely to act to enhance delivery into higher order river channels, optimising the potential for removal from the river catchment. For instance, the mid-elevations $(2100 \mathrm{~m}$ to $3000 \mathrm{~m})$ are the source of the majority $(51 \%)$ of the organic material (in terms of mass per time) eroded from hillslopes by landslides, because these elevations cover the greatest proportion of total basin area (43\%) (Fig. 12a). On a per-area basis (i.e. in $\mathrm{tC} \mathrm{km}^{-2} \mathrm{yr}^{-1}$ ), landslide mobilisation of organic carbon is most frequent at lower elevations (Fig. 12b); while the land area in the Kosñipata study area below $1800 \mathrm{~m}$ elevation comprises $9 \%$ of the total catchment area, $18 \%$ of the organic material stripped by landslides comes from these elevations (Fig. 12a, b).

Second, the landslide-derived organic carbon yield is mostly $(80 \%)$ derived from soil organic matter. This material is finer-grained than coarse woody debris and is thus more likely to be entrained and transported by the Kosñipata River. This observation is consistent with measurements of the isotopic and elemental composition of river-borne particulate organic carbon (POC) in this catchment, which suggest that soil organic carbon from upper horizons appears to be a significant source of biospheric POC (Clark et al., 2013). While the total POC export fluxes from the Kosñipata River are still to be quantified, it is likely that the landslide process offers a mechanism by which large quantities of organic matter, and particularly fine-grained soil organic matter susceptible to fluvial transport, can be supplied from steep hillslopes to river channels.

Finally, our observations are important for understanding the episodic delivery of Andean-derived organic matter to river systems via the landslide process. The distinct focusing of 2010 rain-storm-driven erosion at low elevations of the Kosñipata study catchment demonstrates the potential for landslides triggered by individual storm events to erode material selectively from within a catchment's eleva- tion range. Measurements of biomarker isotope composition in downstream river sediment have shown that organic erosional products reflect distinct elevation sources during storms (Ponton et al., 2014). Together, these results emphasise the potential role for storm events to determine the organic biomarker composition delivered to sediments and to introduce biases relative to the uniform catchment integration often assumed of erosion (Bouchez et al., 2014; Ponton et al., 2014).

\subsection{Timescales of revegetation and implications for ecosystem disturbance and composition}

The biomass and soil removed by landslides is regenerated on hillslopes over time. The duration and dynamics of vegetation recovery influence vegetation structure and soil structure, provide habitat for various species, play an integral role in nutrient cycling, and determine the timescale over which standing stocks of organic carbon are replenished (Restrepo et al., 2009; Bussmann et al., 2008). For the Kosñipata study catchment, we estimate that $100 \%$ of the landslide area from a given year reaches full vegetation cover that is indistinguishable from the surrounding vegetation (based on observable changes from 1988 to 2011 in remote sensing imagery) at $\sim 27 \pm 8$ years after landslide occurrence (Fig. 8). Individual landslides showed large variability; one landslide with a very large area at high elevation, visible in an aerial photo from 1963, is still visible with active portions in 2011, indicating that at least portions of very large landslides may take longer ( $>48$ years) to revegetate, partly due to reactivation. On the other hand, the shortest revegetation time for a landslide occurred within 4 years. In the Bolivian Andes, at sites with similar montane forest and similar elevation range, similar revegetation times of 10 to 35 years were estimated based on dating trees on landslide scars and evaluating canopy closure in aerial photographs (Blodgett and Isacks, 2007). 


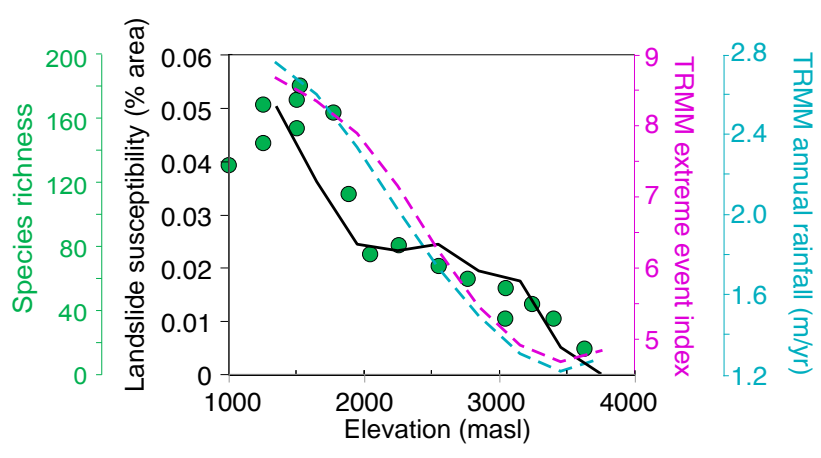

Figure 13. Plots of landslide susceptibility, TRMM-based precipitation (both total annual precipitation and TRMM extreme event index; Bookhagen, 2013), and species richness (number of tree species per ha for trees $>10 \mathrm{~cm}$ diameter at breast height), as a function of elevation within the Kosñipata Valley. Note that absolute values of 2B31 TRMM annual precipitation are not accurate without calibration to meteorological station data (cf. Clark et al., 2014) but spatial patterns may be representative. Climatology, landslide occurrence, and species richness all generally increase from high to low elevations within the Kosñipata Valley, although landslide susceptibility and species richness show a discontinuous trend with elevation while TRMM-based climatology is more continuous.

Although the return to vegetation cover on landslide scars may occur over several decades, it may take much longer, perhaps hundreds of years, to reach the full maturity of a tropical montane cloud forest and to fully replenish soil carbon stocks (Walker et al., 1996). Post-landslide vegetation modelling in the Ecuadorian Andes (1900-2100 m) suggested that initial return of vegetation to landslide surfaces occurs within 80 years after a landslide but that it takes at least 200 years for the post-landslide forest to develop the biomass of a mature tropical montane forest (Dislich and Huth, 2012). The timescale of this full maturation process may be important when considering the impact of landslides on carbon budgets and ecosystem dynamics.

Repeated cycles of landslide activity and revegetation have the potential to introduce disturbance to ecosystems that may affect soil nutrient status, carbon stocks, and even plant biodiversity (Restrepo et al., 2009). Patches of bare rock left by landslides undergo "quasi-primary" succession (Restrepo et al., 2009) that promotes movement of organisms and ecosystem reorganisation (Walker et al., 2013; Hupp, 1983), while inhibiting ecosystem retrogression and nutrient depletion (Peltzer et al., 2010). On landslides in the Bolivian Andes, plant species richness increased from early to late succession and then declined in very mature or senescent forests (Kessler, 1999).

In the Kosñipata Valley, the spatial trends in landslide rate with elevation are similar to trends in plant species richness measured at forest plots (Fig. 13). Similar to landslide activity, species richness is lowest at high elevations, increases slightly with decreasing elevation to $2000 \mathrm{~m}$, and then in- creases abruptly (from 80 to 180 species ha ${ }^{-1}$ ) on forested hillslopes between 2000 and $\sim 1700 \mathrm{~m}$ (Fig. 13). The coincidence of these patterns may reflect the control of both landslides and biodiversity by climatic conditions (e.g. both greater landslide activity and greater biodiversity below the cloud immersion zone). Or the patterns may be simply coincidental, with biodiversity regulated by factors independent of landslide erosion, such as light and temperature, or the transition between lowland/submontane species and montane cloud forest species. We suggest that it may also be possible that the intermediate disturbance regime (Connell, 1978) associated with landslide activity at the lower catchment elevations influences ecosystem structure (Walker et al., 2013; Restrepo et al., 2009; Kessler, 1999; Hupp, 1983) and contributes to enhanced biodiversity observed below $\sim 1700 \mathrm{~m}$. Such effects could be consistent with peaks in species richness at mid-elevations (around $1500 \mathrm{~m}$ ) observed across Andean forest plots in Peru (Fig. 13), Bolivia, and Ecuador (Engemann et al., 2015; Salazar et al., 2015; Girardin et al., 2014b; Huaraca Huasco et al., 2014). A complex mix of geomorphic, climatic, and ecological factors likely influences landslide and biodiversity patterns, but coincidence in our data set provides impetus for future studies of species diversity along geomorphically imposed gradients of disturbance.

\section{Conclusions}

We have quantified the spatial and temporal patterns of landslides over 25-years in the Kosñipata Valley, a forested mountain catchment in the Peruvian Andes. Over the 25-year period, one extreme rainfall event in 2010 triggered $\sim 1 / 4$ of all inventoried landslides, demonstrating the importance of large rainfall events for landslide activity in the Andes. The annual data from this study suggest that the cumulative landslide area associated with smaller, more frequent storms may be similar to the area associated with larger, rarer storms.

The landslides mobilised significant amounts of carbon from forested hillslopes, with an average yield of $26 \pm 4 \mathrm{tC} \mathrm{km}^{-2} \mathrm{yr}^{-1}$. This is one of the largest erosive fluxes of biospheric carbon recorded in a mountain catchment. We estimate that a large proportion of this material was from soil organic matter $\left(20 \pm 3 \mathrm{tC} \mathrm{km}^{-2} \mathrm{yr}^{-1}\right)$ scoured from depths of $\sim 1.5 \mathrm{~m}$ or less, with above- and below-ground biomass marking a smaller yet still important contribution $\left(5.7 \pm 0.8 \mathrm{tC} \mathrm{km}^{-2} \mathrm{yr}^{-1}\right)$. That coupled with the observation that $\sim 90 \%$ of the mapped landslide areas were spatially connected to river channels suggests that this biospheric carbon may be very mobile, and may contribute importantly to suspended sediment export by the Kosñipata River. The onward fate of this carbon will play an important role in determining whether landsliding and physical erosion processes in the Andes contribute a net carbon dioxide source or sink.

Landslides observed in this study were not distributed uniformly across the catchment area, but were focused on slopes 
above a threshold angle (ca. $30-40^{\circ}$ ), consistent with previous studies and theoretical expectations. The highest elevations in the catchment are characterised by low slopes and relatively little landslide activity. Landslides triggered by the large storm in 2010 cluster at low elevations, where precipitation magnitude-frequency relations and catchment morphology hint that such pulses of intense erosional activity may be characteristic of long-term patterns. Such non-uniform erosion would have implications for sources and composition of sediment, organic matter and associated biomarkers and could potentially contribute to influencing forest species composition through patterns of disturbance. Relations between storm activity, landsliding and landscape processes, and ecological function merit further investigation to probe these possible links. 


\section{Appendix A: High-resolution digital elevation model}

For analysing the topography of the Kosñipata study catchment, we used a DEM generated from the Carnegie Airborne Observatory 2 (CAO-2) next-generation Airborne Taxonomic Mapping System (AToMS) with airborne light detection and ranging (lidar; Asner et al., 2012). The CAO data were processed to $1.12 \mathrm{~m}$ spot spacing. Laser ranges from the lidar were combined with the embedded high-resolution global positioning system-inertial measurement unit (GPSIMU) data to determine the 3-D locations of laser returns, producing a "cloud" of lidar data. The lidar data cloud consist of a very large number of georeferenced point elevation estimates $(\mathrm{cm})$, where elevation is relative to a reference ellipsoid (WGS 1984). To estimate canopy height above ground, lidar data points were processed to identify which laser pulses penetrated the canopy volume and reached the ground surface. We used these points to interpolate a raster digital terrain model (DTM) for the ground surface. This was achieved using a $10 \mathrm{~m} \times 10 \mathrm{~m}$ kernel passed over each flight block; the lowest elevation estimate in each kernel was assumed to be ground. Subsequent points were evaluated by fitting a horizontal plane to each of the ground seed points. If the closest unclassified point was $<5.5^{\circ}$ and $<1.5 \mathrm{~m}$ higher in elevation, it was classified as ground. This process was repeated until all points within the block were evaluated. The cell resolution was derived from the DEM resampled in ArcGIS to a $3 \mathrm{~m} \times 3 \mathrm{~m}$ DEM to smooth the topography from a $1.12 \mathrm{~m} \times 1.12 \mathrm{~m}$ DEM. Cells in the topographic shadow area and the area of the catchment with a gap in the data $\left(\sim 3 \mathrm{~km}^{2}\right.$ centralised in the upper elevations) were removed for statistical analysis of the DEM. 


\section{The Supplement related to this article is available online at doi:10.5194/esurf-4-47-2016-supplement.}

Author contributions. K. E. Clark, A. J. West, R. G. Hilton, Y. Malhi, M. New, M. R. Silman, and S. S. Saatchi designed the study; G. P. Asner and R. E. Martin carried out Carnegie Airborne Observatory (CAO) data acquisition and analysis; C. A. Quesada carried out the soil stock fieldwork and geochemical analysis; W. Farfan-Rios and M. R. Silman carried out the above-ground living biomass and plant species diversity fieldwork; A. B. Horwath carried out the epiphyte carbon stock fieldwork; K. Halladay carried out the MODIS cloud cover analysis; K. E. Clark carried out the analysis under the advisement of A. J. West and with contributions from Y. Malhi and R. G. Hilton; and K. E. Clark and A. J. West prepared the manuscript with contributions from all of the co-authors.

Acknowledgements. This paper is a product of the Andes Biodiversity and Ecosystems Research Group (ABERG). K. E. Clark was funded by the Natural Sciences and Engineering Research Council of Canada (NSERC) and Clarendon Fund PhD scholarships. A. J. West was supported to work in the Kosñipata Valley by NSF-EAR 1227192 and R. G. Hilton was supported by a NERC New Investigator Grant (NE/I001719/1). Y. Malhi was supported by the Jackson Foundation and a European Research Council Advanced Investigator Grant GEM-TRAIT. The Carnegie Airborne Observatory is made possible by the Avatar Alliance Foundation, Grantham Foundation for the Protection of the Environment, John D. and Catherine T. MacArthur Foundation, Gordon and Betty Moore Foundation, W. M. Keck Foundation, Margaret A. Cargill Foundation, Mary Anne Nyburg Baker and G. Leonard Baker Jr., and William R. Hearst III. We thank D. Knapp, T. KennedyBowdoin, C. Anderson, and R. Tupayachi for CAO data collection and analysis; M. Palace for the QuickBird-2 satellite images from 2009 and 2010; S. Abele for GIS advice; S. Moon and G. Hilley for providing Matlab code for slope-area analysis; and S. Feakins and reviewers of a prior submission for comments. We thank Ken Ferrier, an anonymous referee, and the editor for their helpful and insightful reviews.

Edited by: G. Govers

\section{References}

ACCA: Weather data San Pedro station, Asociación para la concervación de la cuenca Amazónica, 2012.

Asner, G. P., Powell, G. V., Mascaro, J., Knapp, D. E., Clark, J. K., Jacobson, J., Kennedy-Bowdoin, T., Balaji, A., Paez-Acosta, G., and Victoria, E.: High-resolution forest carbon stocks and emissions in the Amazon, P. Natl. Acad. Sci. USA, 107, 1673816742, doi:10.1073/pnas.1004875107, 2010.

Asner, G. P., Knapp, D. E., Boardman, J., Green, R. O., Kennedy-Bowdoin, T., Eastwood, M., Martin, R. E., Anderson, C., and Field, C. B.: Carnegie Airborne Observatory2: Increasing science data dimensionality via high-fidelity multi-sensor fusion, Remote Sens. Environ., 124, 454-465, doi:10.1016/j.rse.2012.06.012, 2012.

Asner, G. P., Knapp, D. E., Martin, R. E., Tupayachi, R., Anderson, C. B., Mascaro, J., Sinca, F., Chadwick, K. D., Higgins, M., Farfan, W., Llactayo, W., and Silman, M. R.: Targeted carbon conservation at national scales with high-resolution monitoring, P. Natl. Acad. Sci. USA, 111, E5016-E5022, doi:10.1073/pnas.1419550111, 2014.

Barke, R. and Lamb, S.: Late Cenozoic uplift of the Eastern Cordillera, Bolivian Andes, Earth Planet Sc. Lett., 249, 350-367, doi:10.1016/j.eps1.2006.07.012, 2006.

Bilderback, E. L., Pettinga, J. R., Litchfield, N. J., Quigley, M., Marden, M., Roering, J. J., and Palmer, A. S.: Hillslope response to climate-modulated river incision in the Waipaoa catchment, East Coast North Island, New Zealand, Geol. Soc. Am. Bull., 127, 131-148, doi:10.1130/B31015.1, 2015.

Blodgett, T. A. and Isacks, B. L.: Landslide erosion rate in the eastern cordillera of northern Bolivia, Earth Interact., 11, 1-30, doi:10.1175/2007EI222.1, 2007.

Bookhagen, B.: High resolution spatiotemporal distribution of rainfall seasonality and extreme events based on a 12-year TRMM time series http://www.geog.ucsb.edu/ bodo/TRMM/index.php, last access: 06 June 2013.

Bouchez, J., Galy, V., Hilton, R. G., Gaillardet, J., MoreiraTurcq, P., Pérez, M. A., France-Lanord, C., and Maurice, L.: Source, transport and fluxes of Amazon River particulate organic carbon: insights from river sediment depth-profiles, Geochim. Cosmochim. Ac., 133, 280-298, doi:10.1016/j.gca.2014.02.032, 2014.

Brozović, N., Burbank, D. W., and Meigs, A. J.: Climatic limits on landscape development in the Northwestern Himalaya, Science, 276, 571-574, doi:10.1126/science.276.5312.571, 1997.

Burbank, D. W., Leland, J., Fielding, E., Anderson, R. S., Brozovic, N., Reid, M. R., and Duncan, C.: Bedrock incision, rock uplift and threshold hillslopes in the northwestern Himalayas, Nature, 379, 505-510, doi:10.1038/379505a0, 1996.

Bussmann, R. W., Wilcke, W., and Richter, M.: Landslides as important disturbance regimes - Causes and regeneration, in: Gradients in a tropical mountain ecosystem of Ecuador, edited by: Beck, E., Bendix, J., Kottke, I., Makeschin, F., and Mosandl, R., Ecological Studies, 198, Springer-Verlag, Berlin Heildelburg, Germany, 321-330, 2008.

Cabrera, J., Sébrier, M., and Mercier, J. L.: Plio-Quaternary geodynamic evolution of a segment of the Peruvian Andean Cordillera located above the change in the subduction geometry: The Cuzco region, Tectonophysics, 190, 331-362, doi:10.1016/00401951(91)90437-W, 1991.

Carlotto Caillaux, V. S., Rodriguez, G., Fernando, W., Roque, C., Dionicio, J., and Chávez, R.: Geología de los cuadrángulos de Urubamba y Calca, Instituto Geológica Nacional, Lima, Peru, 1996.

Casagli, N., Dapporto, S., Ibsen, M. L., Tofani, V., and Vannocci, P.: Analysis of the landslide triggering mechanism during the storm of 20th-21st November 2000, in Northern Tuscany, Landslides, 3, 13-21, doi:10.1007/s10346-005-0007-y, 2006.

Clark, K. E., Hilton, R. G., West, A. J., Malhi, Y., Gröcke, D. R., Bryant, C. L., Ascough, P. L., Robles Caceres, A., and New, M.: New views on "old" carbon in the Amazon River: Insight from the source of organic carbon eroded from the 
Peruvian Andes, Geochem. Geophy. Geosy., 14, 1644-1659, doi:10.1002/ggge.20122, 2013.

Clark, K. E., Torres, M. A., West, A. J., Hilton, R. G., New, M., Horwath, A. B., Fisher, J. B., Rapp, J. M., Robles Caceres, A., and Malhi, Y.: The hydrological regime of a forested tropical Andean catchment, Hydrol. Earth Syst. Sci., 18, 5377-5397, doi:10.5194/hess-18-5377-2014, 2014.

Clark, M. K., Royden, L. H., Whipple, K. X., Burchfiel, B. C., Zhang, X., and Tang, W.: Use of a regional, relict landscape to measure vertical deformation of the eastern Tibetan Plateau, J. Geophys. Res.-Earth, 111, 1-23, doi:10.1029/2005JF000294, 2006.

Connell, J. H.: Diversity in tropical rain forests and coral reefs, Science, 199, 1302-1310, doi:10.1126/science.199.4335.1302, 1978.

Consbio: Ecosistemas Terrestres de Peru (Data Basin Dataset) for ArcGIS, Covallis, Oregon, USA, 2011.

Crosby, B. T., Whipple, K. X., Gasparini, N. M., and Wobus, C. W.: Formation of fluvial hanging valleys: Theory and simulation, J. Geophys. Res.-Earth, 112, 1-20, doi:10.1029/2006JF000566, 2007.

Dadson, S. J., Hovius, N., Chen, H., Dade, W. B., Lin, J.-C., Hsu, M.-L., Lin, C.-W., Horng, M.-J., Chen, T.-C., Milliman, J., and Stark, C. P.: Earthquake-triggered increase in sediment delivery from an active mountain belt, Geology, 32, 733-736, doi:10.1130/G20639.1, 2004.

Densmore, A. L. and Hovius, N.: Topographic fingerprints of bedrock landslides, Geology, 28, 371-374, doi:10.1130/00917613(2000)?28<371:TFOBL> ?2.0.CO;2, 2000.

DiBiase, R. A. and Whipple, K. X.: The influence of erosion thresholds and runoff variability on the relationships among topography, climate, and erosion rate, J. Geophys. Res.-Earth, 116, 1-17, doi:10.1029/2011JF002095, 2011.

Dislich, C. and Huth, A.: Modelling the impact of shallow landslides on forest structure in tropical montane forests, Ecol. Model., 239, 40-53, doi:10.1016/j.ecolmodel.2012.04.016, 2012.

Dixon, R. K., Brown, S., Houghton, R., Solomon, A., Trexler, M., and Wisniewski, J.: Carbon pools and flux of global forest ecosystems, Science, 263, 185-189, 1994.

Egholm, D. L., Knudsen, M. F., and Sandiford, M.: Lifespan of mountain ranges scaled by feedbacks between landsliding and erosion by rivers, Nature, 498, 475-478, doi:10.1038/nature12218, 2013.

Ekström, G. and Stark, C. P.: Simple scaling of catastrophic landslide dynamics, Science, 339, 1416-1419, doi:10.1126/science.1232887, 2013.

Engemann, K., Enquist, B. J., Sandel, B., Boyle, B., Jørgensen, P. M., Morueta-Holme, N., Peet, R. K., Violle, C., and Svenning, J.C.: Limited sampling hampers "big data" estimation of species richness in a tropical biodiversity hotspot, Ecol. Evol., 5, 807820, doi:10.1002/ece3.1405, 2015.

Espinoza, J. C., Chavez, S., Ronchail, J., Junquas, C., Takahashi, K., and Lavado, W.: Rainfall hotspots over the southern tropical Andes: Spatial distribution, rainfall intensity, and relations with large-scale atmospheric circulation, Water Resour. Res., 51, 117, doi:10.1002/2014WR016273, 2015.
Eswaran, H., Van Den Berg, E., and Reich, P.: Organic Carbon in Soils of the World, Soil Sci. Soc. Am. J., 57, 192-194, doi:10.2136/sssaj1993.03615995005700010034x, 1993.

Farr, T. G., Rosen, P. A., Caro, E., Crippen, R., Duren, R., Hensley, S., Kobrick, M., Paller, M., Rodriguez, E., Roth, L., Seal, D., Shaffer, S., Shimada, J., Umland, J., Werner, M., Oskin, M., Burbank, D., and Alsdorf, D.: The Shuttle Radar Topography Mission, Rev. Geophys., 45, RG2004, doi:10.1029/2005RG000183, 2007.

Ferrier, K. L., Huppert, K. L., and Perron, J. T.: Climatic control of bedrock river incision, Nature, 496, 206-209, doi:10.1038/nature11982, 2013.

Gallen, S. F., Clark, M. K., and Godt, J. W.: Coseismic landslides reveal near-surface rock strength in a high-relief tectonically active setting, Geology, 43, 70-70, doi:10.1130/G36080.1, 2015.

Galy, V., Peucker-Ehrenbrink, B., and Eglinton, T.: Global carbon export from the terrestrial biosphere controlled by erosion, Nature, 521, 204-207, doi:10.1038/nature14400, 2015.

Gasparini, N. M. and Whipple, K. X.: Diagnosing climatic and tectonic controls on topography: Eastern flank of the northern Bolivian Andes, Lithosphere, 6, 230-250, doi:10.1130/1322.1, 2014.

Gibbon, A., Silman, M. R., Malhi, Y., Fisher, J. B., Meir, P., Zimmermann, M., Dargie, G. C., Farfan, W. R., and Garcia, K. C.: Ecosystem carbon storage across the grassland-forest transition in the high Andes of Manu National Park, Peru, Ecosystems, 13, 1097-1111, doi:10.1007/s10021-010-9376-8, 2010.

Gilbert, G. K.: Geology of the Henry Mountains, Geology of the Henry Mountains, Washington, D.C., Report, i-160 pp., 1877.

Girardin, C. A. J., Malhi, Y., Aragao, L. E. O. C., Mamani, M., Huasco, W. H., Durand, L., Feeley, K. J., Rapp, J., Silva-Espejo, J. E., Silman, M., Salinas, N., and Whittaker, R. J.: Net primary productivity allocation and cycling of carbon along a tropical forest elevational transect in the Peruvian Andes, Glob. Change Biol., 16, 3176-3192, doi:10.1111/j.1365-2486.2010.02235.x, 2010.

Girardin, C. A. J., Aragão, L. E. O. C., Malhi, Y., Huaraca Huasco, W., Metcalfe, D. B., Durand, L., Mamani, M., Silva-Espejo, J. E., and Whittaker, R. J.: Fine root dynamics along an elevational gradient in tropical Amazonian and Andean forests, Global Biogeochem. Cy., 27, 252-264, doi:10.1029/2011GB004082, 2013.

Girardin, C. A. J., Malhi, Y., Feeley, K. J., Rapp, J. M., Silman, M. R., Meir, P., Huaraca Huasco, W., Salinas, N., Mamani, M., Silva-Espejo, J. E., García Cabrera, K., Farfan Rios, W., Metcalfe, D. B., Doughty, C. E., and Aragão, L. E. O. C.: Seasonality of above-ground net primary productivity along an Andean altitudinal transect in Peru, J. Trop. Ecol., 30, 503-519, doi:10.1017/S0266467414000443, 2014a.

Girardin, C. A. J., Silva-Espejo, J. E., Doughty, C. E., Huaraca Huasco, W., Metcalfe, D. B., Durand-Baca, L., Marthews, T. R., Aragao, L. E. O. C., Farfan Rios, W., García Cabrera, K., Halladay, K., Fisher, J. B., Galiano-Cabrera, D. F., HuaracaQuispe, L. P., Alzamora-Taype, I., Equiluz-Mora, L., SalinasRevilla, N., Silman, M., Meir, P., and Malhi, Y.: Productivity and carbon allocation in a tropical montane cloud forest of the Peruvian Andes, Plant Ecol. Divers., 7, 107-123, doi:10.1080/17550874.2013.820222, 2014b.

Glade, T.: Establishing the frequency and magnitude of landslidetriggering rainstorm events in New Zealand, Eng. Geol., 35, 160174, doi:10.1007/s002540050302, 1998. 
Gregory-Wodzicki, K. M.: Uplift history of the Central and Northern Andes: A review, Geol. Soc. Am. Bull., 112, 1091-1105, doi:10.1130/0016-7606(2000)112<1091:UHOTCA> 2.0.CO;2, 2000.

Gubbels, T. L., Isacks, B. L., and Farrar, E.: High-level surfaces, plateau uplift, and foreland development, Bolivian central Andes, Geology, 21, 695-698, doi:10.1130/00917613(1993)021<0695:hlspua> 2.3.co;2, 1993.

Gurdak, D. J., Aragao, L. E. O. C., Rozas-Dávila, A., Huaraca Huasco, W., García Cabrera, K., Doughty, C. E., Farfan-Rios, W., Silva-Espejo, J. E., Metcalfe, D. B., Silman, M. R., and Malhi, Y.: Assessing above-ground woody debris dynamics along a gradient of elevation in Amazonian cloud forests in Peru: balancing above-ground inputs and respriation outputs, Plant Ecol. Divers., 7, 143-160, doi:10.1080/17550874.2013.818073, 2014.

Guzzetti, F., Peruccacci, S., Rossi, M., and Stark, C. P.: Rainfall thresholds for the initiation of landslides in central and southern Europe, Meteorol. Atmos. Phys., 98, 239-267, doi:10.1007/s00703-007-0262-7, 2007.

Halladay, K., Malhi, Y., and New, M.: Cloud frequency climatology at the Andes/Amazon transition: 1. Seasonal and diurnal cycles, J. Geophys. Res., 117, D23102, doi:10.1029/2012JD017770, 2012.

Hilton, R. G., Galy, A., and Hovius, N.: Riverine particulate organic carbon from an active mountain belt: Importance of landslides, Global Biogeochem. Cy., 22, BG1017, doi:10.1029/2006GB002905, 2008a.

Hilton, R. G., Galy, A., Hovius, N., Chen, M.-C., Horng, M.J., and Chen, H.: Tropical-cyclone-driven erosion of the terrestrial biosphere from mountains, Nat. Geosci., 1, 759-762, doi:10.1038/ngeo333, 2008b.

Hilton, R. G., Meunier, P., Hovius, N., Bellingham, P. J., and Galy, A.: Landslide impact on organic carbon cycling in a temperate montane forest, Earth Surf. Proc. Land., 36, 1670-1679, doi:10.1002/esp.2191, 2011.

Hilton, R. G., Gaillardet, J., Calmels, D., and Birck, J.-L.: Geological respiration of a mountain belt revealed by the trace element rhenium, Earth Planet Sc. Lett., 403, 27-36, doi:10.1016/j.epsl.2014.06.021, 2014.

Horwath, A.: Epiphytic bryophytes as cloud forest indicators: Stable isotopes, biomass and diversity along an altitudinal gradient in Peru, Doctor of Philosophy, Plant Sciences, University of Cambridge, Cambridge, 260 pp., 2011.

Hovius, N., Stark, C. P., and Allen, P. A.: Sediment flux from a mountain belt derived by landslide mapping, Geology, 25, 231234, doi:10.1130/0091-7613(1997)025<0231:sffamb> 2.3.co;2, 1997.

Hovius, N., Stark, C. P., Chu, H. T., and Lin, J. C.: Supply and removal of sediment in a landslide-dominated mountain belt: Central Range, Taiwan, J. Geol., 108, 73-89, doi:10.1086/314387, 2000.

Huaraca Huasco, W., Girardin, C. A. J., Doughty, C. E., Metcalfe, D. B., Baca, L. D., Silva-Espejo, J. E., Cabrera, D. G., Aragão, L. E. O., Davila, A. R., Marthews, T. R., HuaracaQuispe, L. P., Alzamora-Taype, I., Eguiluz-Mora, L., FarfanRios, W., Cabrera, K. G., Halladay, K., Salinas-Revilla, N., Silman, M., Meir, P., and Malhi, Y.: Seasonal production, allocation and cycling of carbon in two mid-elevation tropical montane for- est plots in the Peruvian Andes, Plant Ecol. Divers., 1-2, 125 142, doi:10.1080/17550874.2013.819042, 2014.

Hupp, C. R.: Seedling establishment on a landslide site, Castanea, 48, 89-98, 1983.

INGEMMET: GEOCATMIN - Geologia integrada por proyectos regionales, Lima, Peru, 2013.

Keefer, D. K.: The importance of earthquake-induced landslides to long-term slope erosion and slope-failure hazards in seismically active regions, Geomorphology, 10, 265-284, doi:10.1016/0169555X(94)90021-3, 1994.

Kessler, M.: Plant species richness and endemism during natural landslide succession in a perhumid montane forest in the Bolivian Andes, Ecotropica, 5, 123-136, 1999.

Lague, D., Hovius, N., and Davy, P.: Discharge, discharge variability, and the bedrock channel profile, J. Geophys. Res.-Earth, 110 1-17, doi:10.1029/2004JF000259, 2005.

Larsen, I. J., Montgomery, D. R., and Korup, O.: Landslide erosion controlled by hillslope material, Nat. Geosci., 3, 247-251, doi:10.1038/ngeo776, 2010.

Larsen, I. J. and Montgomery, D. R.: Landslide erosion coupled to tectonics and river incision, Nat. Geosci., 5, 468-473, doi:10.1038/ngeo1479, 2012.

Larsen, M. C. and Simon, A.: A rainfall intensity-duration threshold for landslides in a humid-tropical environment, Puerto Rico, Geogr. Ann. A., 75, 13-23, doi:10.2307/521049, 1993.

Li, G., West, A. J., Densmore, A. L., Jin, Z., Parker, R. N., and Hilton, R. G.: Seismic mountain building: Landslides associated with the 2008 Wenchuan earthquake in the context of a generalized model for earthquake volume balance, Geochem. Geophy. Geosy., 15, 833-844, doi:10.1002/2013GC005067, 2014.

Lin, G.-W., Chen, H., Hovius, N., Horng, M.-J., Dadson, S., Meunier, P., and Lines, M.: Effects of earthquake and cyclone sequencing on landsliding and fluvial sediment transfer in a mountain catchment, Earth Surf. Proc. Land., 33, 1354-1373, doi:10.1002/esp.1716, 2008.

Lowman, L. E. L. and Barros, A. P.: Investigating links between climate and orography in the Central Andes: Coupling erosion and precipitation using a physical-statistical model, J. Geophys. Res.-Earth, 119, 1322-1353, doi:10.1002/2013JF002940, 2014.

Malamud, B. D., Turcotte, D. L., Guzzetti, F., and Reichenbach, P.: Landslide inventories and their statistical properties, Earth Surf. Proc. Land., 29, 687-711, doi:10.1002/esp.1064, 2004.

Malhi, Y., Silman, M., Salinas, N., Bush, M., Meir, P., and Saatchi, S.: Introduction: Elevation gradients in the tropics: Laboratories for ecosystem ecology and global change research, Glob. Change Biol., 16, 3171-3175, doi:10.1111/j.1365-2486.2010.02323.x, 2010 .

Marc, O. and Hovius, N.: Amalgamation in landslide maps: effects and automatic detection, Nat. Hazards Earth Syst. Sci., 15, 723733, doi:10.5194/nhess-15-723-2015, 2015.

Marengo, J. A., Soares, W. R., Saulo, C., and Nicolini, M.: Climatology of the low-level jet east of the Andes as derived from the NCEP-NCAR reanalyses: Characteristics and temporal variability, J. Climate, 17, 2261-2280, doi:10.1175/15200442(2004)017<2261:COTLJE>2.0.CO;2, 2004.

Marvin, D. C., Asner, G. P., Knapp, D. E., Anderson, C. B., Martin, R. E., Sinca, F., and Tupayachi, R.: Amazonian landscapes and the bias in field studies of forest structure 
and biomass, P. Natl. Acad. Sci. USA, 111, E5224-E5232, doi:10.1073/pnas.1412999111, 2014.

Mendívil Echevarría, S., and Dávila Manrique, D.: Geología de los cuadrángulos de Cuzco y Livitaca, Instituto Geológica Nacional, Lima, Peru, 1994.

METI/NASA: ASTER Global DEM product, NASA EOSDIS Land Processes DAAC USGS Earth Resources Observation and Science (EROS) Center Sioux Falls, South Dakota, USA, 2009.

Meunier, P., Hovius, N., and Haines, J. A.: Topographic site effects and the location of earthquake induced landslides, Earth Planet Sc. Lett., 275, 221-232, doi:10.1016/j.epsl.2008.07.020, 2008.

Montgomery, D. R. and Buffington, J. M.: Channelreach morphology in mountain drainage basins, Geol. Soc. Am. Bull., 109, 596-611, doi:10.1130/00167606(1997)109<0596:CRMIMD> 2.3.CO;2, 1997.

Montgomery, D. R.: Slope distributions, threshold hillslopes, and steady-state topography, Am. J. Sci., 301, 432-454, doi:10.2475/ajs.301.4-5.432, 2001.

Montgomery, D. R. and Brandon, M. T.: Topographic controls on erosion rates in tectonically active mountain ranges, Earth Planet Sc. Lett., 201, 481-489, doi:10.1016/S0012-821X(02)00725-2, 2002.

Moon, S., Chamberlain, C. P., Blisniuk, K., Levine, D. H., Rood, D. H., and Hilley, G. E.: Climatic control of denudation in the deglaciated landscape of the Washington Cascades, Nat. Geosci., 4, 469-473, doi:10.1038/ngeo1159, 2011.

Oskin, M. and Burbank, D. W.: Alpine landscape evolution dominated by cirque retreat, Geology, 33, 933-936, doi:10.1130/G21957.1, 2005.

Peltzer, D. A., Wardle, D. A., Allison, V. J., Baisden, W. T., Bardgett, R. D., Chadwick, O. A., Condron, L. M., Parfitt, R. L., Porder, S., and Richardson, S. J.: Understanding ecosystem retrogression, Ecol. Mongr., 80, 509-529, doi:10.1890/09-1552.1, 2010.

Pepin, E., Guyot, J. L., Armijos, E., Bazan, H., Fraizy, P., Moquet, J. S., Noriega, L., Lavado, W., Pombosa, R., and Vauchel, P.: Climatic control on eastern Andean denudation rates (Central Cordillera from Ecuador to Bolivia), J. S. Am. Earth Sci., 44, 85-93, doi:10.1016/j.jsames.2012.12.010, 2013.

Ponton, C., West, A. J., Feakins, S. J., and Galy, V.: Leaf wax biomarkers in transit record river catchment composition, Geophys. Res. Lett., 41, 6420-6427, doi:10.1002/2014GL061328, 2014.

Quesada, C. A., Lloyd, J., Schwarz, M., Patiño, S., Baker, T. R., Czimczik, C., Fyllas, N. M., Martinelli, L., Nardoto, G. B., Schmerler, J., Santos, A. J. B., Hodnett, M. G., Herrera, R., Luizão, F. J., Arneth, A., Lloyd, G., Dezzeo, N., Hilke, I., Kuhlmann, I., Raessler, M., Brand, W. A., Geilmann, H., Moraes Filho, J. O., Carvalho, F. P., Araujo Filho, R. N., Chaves, J. E., Cruz Junior, O. F., Pimentel, T. P., and Paiva, R.: Variations in chemical and physical properties of Amazon forest soils in relation to their genesis, Biogeosciences, 7, 1515-1541, doi:10.5194/bg-7-15152010, 2010.

Raich, J. W., Russell, A. E., Kitayama, K., Parton, W. J., and Vitousek, P. M.: Temperature influences carbon accumulation in moist tropical forests, Ecology, 87, 76-87, doi:10.1890/05-0023, 2006.

Ramos Scharrón, C. E., Castellanos, E. J., and Restrepo, C.: The transfer of modern organic carbon by landslide activity in tropical montane ecosystems, J. Geophys. Res.-Biogeo., 117, G03016, doi:10.1029/2011JG001838, 2012.

Rao, Y.: Variation in plant carbon and nitrogen isotopes along an altitudinal gradient in the Peruvian Andes, B. Sc., Department of Earth Sciences, Durham University, Durham, 60 pp., 2011.

Restrepo, C., Vitousek, P., and Neville, P.: Landslides significantly alter land cover and the distribution of biomass: an example from the Ninole ridges of Hawai'i, Plant Ecol., 166, 131-143, doi:10.1023/A:1023225419111, 2003.

Restrepo, C. and Alvarez, N.: Landslides and their contribution to land-cover change in the mountains of Mexico and Central America, Biotropica, 38, 446-457, doi:10.1111/j.17447429.2006.00178.x, 2006.

Restrepo, C., Walker, L. R., Shiels, A. B., Bussmann, R., Claessens, L., Fisch, S., Lozano, P., Negi, G., Paolini, L., and Poveda, G.: Landsliding and its multiscale influence on mountainscapes, Bioscience, 59, 685-698, doi:10.1525/bio.2009.59.8.10, 2009.

Roering, J. J., Kirchner, J. W., and Dietrich, W. E.: Characterizing structural and lithologic controls on deep-seated landsliding: Implications for topographic relief and landscape evolution in the Oregon Coast Range, USA, Geol. Soc. Am. Bull., 117, 654-668, doi:10.1130/B25567.1, 2005.

Roering, J. J., Mackey, B. H., Handwerger, A. L., Booth, A. M., Schmidt, D. A., Bennett, G. L., and Cerovski-Darriau, C.: Beyond the angle of repose: A review and synthesis of landslide processes in response to rapid uplift, Eel River, Northern California, Geomorphology, 236, 109-131, doi:10.1016/j.geomorph.2015.02.013, 2015.

Rohrmann, A., Strecker, M. R., Bookhagen, B., Mulch, A., Sachse, D., Pingel, H., Alonso, R. N., Schildgen, T. F., and Montero, C.: Can stable isotopes ride out the storms? The role of convection for water isotopes in models, records, and paleoaltimetry studies in the central Andes, Earth Planet Sc. Lett., 407, 187-195, doi:10.1016/j.epsl.2014.09.021, 2014.

Saatchi, S. S., Houghton, R. A., Dos Santos AlvalÁ, R. C., Soares, J. V., and Yu, Y.: Distribution of aboveground live biomass in the Amazon basin, Glob. Change Biol., 13, 816-837, doi:10.1111/j.1365-2486.2007.01323.x, 2007.

Saatchi, S. S., Harris, N. L., Brown, S., Lefsky, M., Mitchard, E. T., Salas, W., Zutta, B. R., Buermann, W., Lewis, S. L., and Hagen, S.: Benchmark map of forest carbon stocks in tropical regions across three continents, P. Natl. Acad. Sci. USA, 108, 9899-9904, doi:10.1073/pnas.1019576108, 2011.

Safran, E. B., Bierman, P. R., Aalto, R., Dunne, T., Whipple, K. X., and Caffee, M.: Erosion rates driven by channel network incision in the Bolivian Andes, Earth Surf. Proc. Land., 30, 1007-1024, doi:10.1002/esp.1259, 2005.

Salazar, L., Homeier, J., Kessler, M., Abrahamczyk, S., Lehnert, M., Krömer, T., and Kluge, J.: Diversity patterns of ferns along elevational gradients in Andean tropical forests, Plant Ecol. Divers., 8, 13-24, doi:10.1080/17550874.2013.843036, 2015.

Schmidt, K. M. and Montgomery, D. R.: Limits to relief, Science, 270, 617-620, doi:10.1126/science.270.5236.617, 1995.

Sébrier, M., Mercier, J. L., Mégard, F., Laubacher, G., and CareyGailhardis, E.: Quaternary normal and reverse faulting and the state of stress in the central Andes of south Peru, Tectonics, 4, 739-780, doi:10.1029/TC004i007p00739, 1985.

Selby, M.: Hillslope materials and processes, Oxford University Press, Oxford, UK, 289 pp., 1993. 
Stallard, R. F.: River chemistry, geology, geomorphology, and soils in the Amazon and Orinoco Basins, The chemistry of weathering, Rodez, France, 293-316, 1985.

Stallard, R. F.: Terrestrial sedimentation and the carbon cycle: Coupling weathering and erosion to carbon burial, Global Biogeochem. Cy., 12, 231-257, doi:10.1029/98gb00741, 1998.

Stark, C. P. and Hovius, N.: The characterization of landslide size distributions, Geophys. Res. Lett., 28, 1091-1094, doi:10.1029/2000GL008527, 2001.

Stock, J. and Dietrich, W. E.: Valley incision by debris flows: Evidence of a topographic signature, Water Resour. Res., 39, 1-24, doi:10.1029/2001WR001057, 2003.

Stoyan, R.: Aktivität, Ursachen und Klassifikation der Rutschungen in San Francisco/Süd Ecuador, Diploma, University of ErlangenNuremberg, Erlangen, Germany, 2000.

Strecker, M. R., Alonso, R. N., Bookhagen, B., Carrapa, B., Hilley, G. E., Sobel, E. R., and Trauth, M. H.: Tectonics and climate of the Southern Central Andes, Annu. Rev. Earth Pl. Sc., 35, 747787, doi:10.1146/annurev.earth.35.031306.140158, 2007.

Tavera, H. and Buforn, E.: Source mechanism of earthquakes in Perú, J. Seismol., 5, 519-540, doi:10.1023/A:1012027430555, 2001.

Terzaghi, K.: Mechanism of landslides, Harvard University, Department of Engineering, Cambridge, Massachusetts, USA, 41 pp., 1951.

USGS: Earthquakes v3.6, 2013-07-02, USGS, http://earthquake. usgs.gov/earthquakes/map/, last access: 2 July 2013a.

USGS: Landsat Processing Details, United States Geological Survey, U.S. Deptarment of the Interior, http://landsat.usgs.gov/ Landsat_Processing_Details.php, last access: 16 July 2013b.

Vargas Vilchez, L. and Hipolito Romero, A.: Geología de los cuadrángulos de Río Pinquén, Pilcopata y Chontachaca. Hojas: 25-t, 26-t y 27-t, Instituto Geológica Nacional, Lima, Peru, 1998.

Walker, L. R., Zarin, D. J., Fetcher, N., Myster, R. W., and Johnson, A. H.: Ecosystem development and plant succession on landslides in the Caribbean, Biotropica, 28, 566-576, doi:10.2307/2389097, 1996.

Walker, L. R., Shiels, A. B., Bellingham, P. J., Sparrow, A. D., Fetcher, N., Landau, F. H., and Lodge, D. J.: Changes in abiotic influences on seed plants and ferns during 18 years of primary succession on Puerto Rican landslides, J. Ecol., 101, 650-661, doi:10.1111/1365-2745.12071, 2013.

Wang, G. and Sassa, K.: Pore-pressure generation and movement of rainfall-induced landslides: effects of grain size and fineparticle content, Eng. Geol., 69, 109-125, doi:10.1016/S00137952(02)00268-5, 2003.
Wang, J., Jin, Z., Hilton, R. G., Zhang, F., Densmore, A. L., Li, G., and West, A. J.: Controls on fluvial evacuation of sediment from earthquake-triggered landslides, Geology, 43, 115118, doi:10.1130/G36157.1, 2015.

West, A. J., Lin, C. W., Lin, T. C., Hilton, R. G., Liu, S. H., Chang, C. T., Lin, K. C., Galy, A., Sparkes, R. B., and Hovius, N.: Mobilization and transport of coarse woody debris to the oceans triggered by an extreme tropical storm, Limnol. Oceanogr., 56, 77-85, doi:10.4319/lo.2011.56.1.0077, 2011.

Whipple, K. X.: Fluvial landscape response time: How plausible is steady-state denudation?, Am. J. Sci., 301, 313-325, doi:10.2475/ajs.301.4-5.313, 2001.

Whipple, K. X.: Bedrock rivers and the geomorphology of active orogens, Annu. Rev. Earth Pl. Sc., 32, 151-185, doi:10.1146/annurev.earth.32.101802.120356, 2004.

Whipple, K. X. and Gasparini, N. M.: Tectonic control of topography, rainfall patterns, and erosion during rapid post$12 \mathrm{Ma}$ uplift of the Bolivian Andes, Lithosphere, 6, 251-268, doi:10.1130/1325.1, 2014.

Wittmann, H., von Blanckenburg, F., Guyot, J. L., Maurice, L., and Kubik, P.: From source to sink: Preserving the cosmogenic ${ }^{10} \mathrm{Be}-$ derived denudation rate signal of the Bolivian Andes in sediment of the Beni and Mamoré foreland basins, Earth Planet Sc. Lett., 288, 463-474, doi:10.1016/j.epsl.2009.10.008, 2009.

Wohl, E. and Ogden, F. L.: Organic carbon export in the form of wood during an extreme tropical storm, Upper Rio Chagres, Panama, Earth Surf. Proc. Land., 38, 1407-1416, doi:10.1002/esp.3389, 2013.

Wolman, M. G. and Miller, J. P.: Magnitude and frequency of forces in geomorphic processes, J. Geol., 68, 54-74, 1960.

Yang, R., Willett, S. D., and Goren, L.: In situ low-relief landscape formation as a result of river network disruption, Nature, 520, 526-529, doi:10.1038/nature14354, 2015.

Yoo, K., Amundson, R., Heimsath, A. M., and Dietrich, W. E.: Erosion of upland hillslope soil organic carbon: Coupling field measurements with a sediment transport model, Global Biogeochem. Cy., 19, GB3003, doi:10.1029/2004GB002271, 2005.

Zhang, W. and Montgomery, D. R.: Digital elevation model grid size, landscape representation, Water Resour. Res., 30, 10191028, 1994.

Zimmermann, M., Meir, P., Bird, M. I., Malhi, Y., and Ccahuana, A. J. Q.: Climate dependence of heterotrophic soil respiration from a soil-translocation experiment along a $3000 \mathrm{~m}$ tropical forest altitudinal gradient, Eur. J. Soil Sci., 60, 895-906, doi:10.1111/j.1365-2389.2009.01175.x, 2009. 